\title{
A Tale of Two Sovereigns: Federal and State Use and Regulation of Unmanned Aircraft Systems
}

Laura K. Donohue

Georgetown University Law Center, Ikdonohue@law.georgetown.edu

This paper can be downloaded free of charge from:

https://scholarship.law.georgetown.edu/facpub/1967

https://ssrn.com/abstract=2943018

Laura K. Donohue, A Tale of Two Sovereigns: Federal and State Use and Regulation of Unmanned Aircraft Systems, in Handbook of Unmanned Aerial Vehicles (Kimon P. Valavanis \& George J. Vachtsevanos eds., Springer International Publishing AG 2d ed. forthcoming)

This open-access article is brought to you by the Georgetown Law Library. Posted with permission of the author. Follow this and additional works at: https://scholarship.law.georgetown.edu/facpub

Part of the Air and Space Law Commons, and the State and Local Government Law Commons 


\title{
A Tale of Two Sovereigns: Federal and State Use and Regulation of Unmanned Aircraft Systems
}

\author{
Laura K. Donohue
}

\section{Contents}

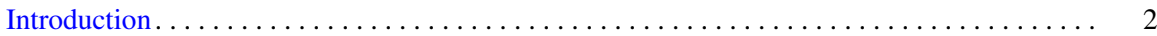

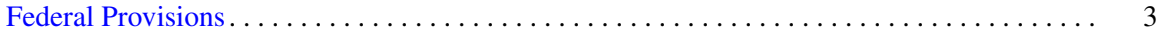

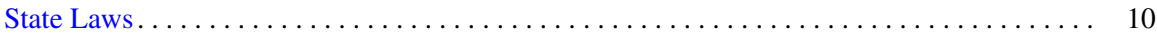

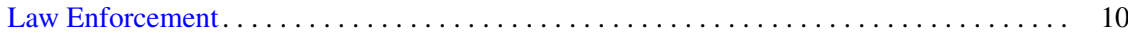

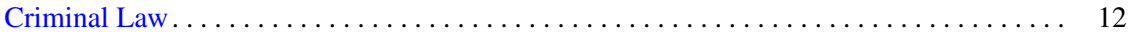

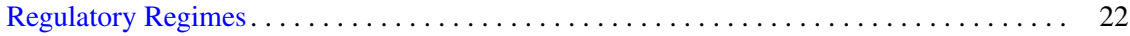

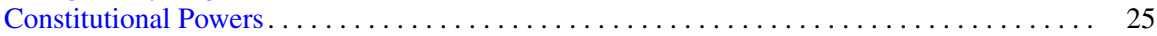

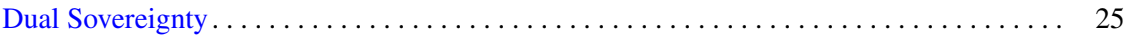

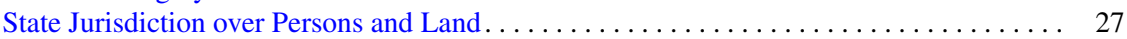

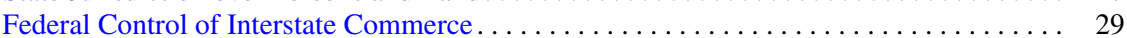

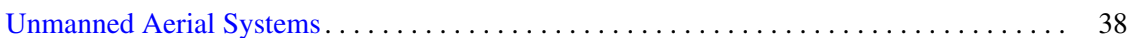

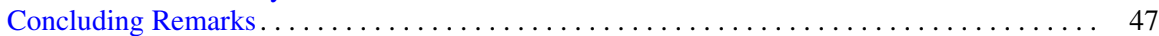

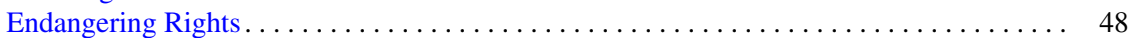

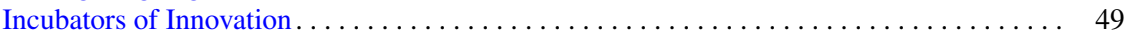

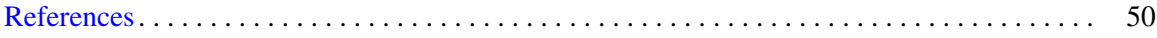

\begin{abstract}
Despite claims to the contrary, the federal government is severely limited in what it can do to regulate unmanned aircraft systems (UASs). States, on the other hand, as governments of general jurisdiction, have expansive powers that
\end{abstract}

Special thanks to Julie Hwang, Sora Kim, Kyle Henne, Ron Havas, Juyoun Han, Sara Burriesci, Nicholas Johnson, Matthew Palucki, Darci Stanger, Morgan Stoddard, and Jeremy McCabe for their research assistance and to Dawn Zoldi for her comments on earlier versions of this chapter.

L. K. Donohue (西)

Georgetown Law, Washington, DC, USA

e-mail: 1kdonohue@law.georgetown.edu

K. P. Valavanis, G. J. Vachtsevanos (eds.), Handbook of Unmanned Aerial Vehicles, https://doi.org/10.1007/978-3-319-32193-6_166-1 
they are already using to grapple with the questions posed by UAS related to privacy, crime, and public safety. This chapter outlines the evolution of federal measures, noting their limitations, before delving into three categories of state law, related to law enforcement, criminal measures, and regulatory regimes. The chapter then turns to the history of state sovereignty, looking at states' jurisdiction over persons and land within their bounds, before turning to the limits of federal interstate commerce authorities. With river navigation and aviation serving as the forerunners of federal power, the chapter distinguishes the types of questions that accompany UAS, arguing that it is in relation to adjacent airspace and noneconomic activities where the federal government is at its weakest in any effort to regulate the states. Up to $500 \mathrm{ft}$ above the ground, states have sovereignty, with authority over roads, land, and waterways. Within this domain, federal Commerce Clause powers only occupy a narrow area, leaving state police powers the dominant framework for UAS. The chapter concludes by highlighting the advantages of having states take the lead for UAS, focusing on the risk to rights of allowing the federal government to move into this realm and underscoring the importance in the role of the states as incubators of innovation.

\section{Keywords}

Drones · Unmanned aerial vehicles · Unmanned aerial systems · UAV ·

UAS · Preemption · State · Federal · Local · Law · Weaponization ·

Regulation

\section{Introduction}

In 2014 the Federal Aviation Administration (FAA) posted an article on its website entitled, Busting Myths about the FAA and Unmanned Aircraft. Exhibit \#1 was the "myth" that "The FAA doesn't control airspace below 400 feet." To the contrary, the agency claimed, "The FAA is responsible for the safety of U.S. airspace from the ground up" ("Busting Myths" 2014).

In some respects, the statement offered by the FAA is correct - the agency is responsible for the safety of the National Airspace System (NAS). But it also is deeply misleading and, in other respects, blatantly wrong. While the FAA is responsible for safety, there are numerous areas in which the FAA is severely constrained in what it can do vis-à-vis unmanned aircraft systems (UASs), even as it has little to no claim to the air just above the ground. States have dominance in the airspace between the land and the NAS, as well as in how the technology is used within the state. Efforts by the federal government to control UAS outside the NAS may violate state sovereignty and, as such, fall afoul of constitutional constraints. Outside of the involvement of UAS in interstate commerce, neither the FAA nor Congress can regulate the uses of UAS by either private or public actors within state bounds. For that, we must look to the states, where we are seeing a tremendous amount of innovation. 
This chapter begins by outlining what the federal government has done to regulate UAS within state bounds, noting the limits of federal regulations. It then turns to the explosion in state UAS laws 2013-2017, noting the rich and varied approaches that have been taken at a local level to the questions posed by UAS. It highlights three categories of state measures: law enforcement, criminal provisions, and regulatory measures.

The first category focuses on restrictions placed on law enforcement. The chapter details provisions dealing with surveillance, weaponization, data retention, information sharing, arrest, home detention, crime scene documentation and reconstruction, traffic enforcement, motor vehicle accidents, and border and port authorities. States regulate emergency service use of UAS, indemnifying first responders who force UAS out of the sky.

The second category focuses on criminal law, where a plethora of new measures have appeared. In addition to making it illegal to interfere with law enforcement, states have passed laws forbidding the use of UAS to trespass, to engage in voyeurism, to stalk, or to harass others. A few states have outlawed the weaponization of UAS. Considerably more states forbid the use of UAS for hunting and fishing - or for harassing those engaged in the same. Criminal law in some states forbids flying UAS over correctional facilities, while other states have broader restrictions on flight over, or interference in the operation of critical infrastructure facilities.

The third category, regulatory measures, includes restrictions on the takeoff and landing of drones, their use in agricultural operations, special tax incentives, and, despite the federal measures that have been adopted, state training and certification programs. Other measures relate to research and mapping and the creation of study groups to consider the long-term opportunities and risks posed by UAS.

Although the FAA claims broad power to regulate UAS from the ground up, states, as reflected in the myriad UAS measures that have been introduced, have long had jurisdiction over persons and land within their bounds. Constitutional provisions and case law suggest that up to $500 \mathrm{ft}$ in the adjacent airspace, states have primacy. While Commerce Clause authorities may preempt some state measures, when it comes to adjacent airspace, noneconomic activities, and many aspects of event economic activity, states are in the stronger constitutional position.

The chapter ends by pointing out that in addition to constitutional considerations, two further concerns suggest more limited federal involvement, namely, the risk to individual rights that accompanies federal control and the importance of protecting state sovereignty to allow states to serve as incubators of innovation.

\section{Federal Provisions}

On June 9, 1981, the FAA issued its first guidance for model aircraft. One page long, the circular advised that operators select sites "of sufficient distance from populated areas" and away from "noise sensitive areas such as parks, schools, hospitals, [and] churches." It directed that pilots not fly aircraft more than $400 \mathrm{ft}$ high and, when 
within 3 miles of an airport, notify the flight tower. In the event that model aircraft confronted full-scale aircraft, the FAA advised model aircraft pilots to give way (Federal Aviation Administration 1981).

These provisions were not enforceable. There were no penalties attached. Nor, arguably, could the federal government regulate private citizens' use of model aircraft on their own properties. As a constitutional matter, it was only when the planes might interfere with commercial aircraft that the federal government could step in. The guidelines thus amounted to advice for how to avoid such a circumstance. For a quarter of a century, these guidelines were sufficient.

But as UAS became increasingly sophisticated, the FAA had to confront their potential flight in navigable airspace. Accordingly, in 2007 the FAA issued a new policy. The document defined unmanned aircraft broadly as any device intended to be used in the air with no onboard pilot (Unmanned Aircraft Operations in the National Airspace System 2007; see also 49 U.S.C. $\$ 40102$ 2016; 14 C.F.R. § $1.12016)$. The FAA acknowledged that the definition incorporated everything from remote controlled airplanes to military remotely piloted aircraft (RPA) (Unmanned Aircraft Operations in the National Airspace System, 2007). Whether the wing span of such devices be 6 in. or $246 \mathrm{ft}$, "The one thing they have in common," the FAA stated, "is that their numbers and uses are growing dramatically" (Unmanned Aircraft Operations in the National Airspace System 2007). Safety was paramount.

The FAA based its approach on the purpose for which the aircraft was being flown: public aircraft, civil aircraft, or model aircraft. The prior guidelines largely covered the third category, model aircraft. New rules had to be developed for the first two areas.

Combat RPAs flown in overseas combat, or deployed along the US border with Mexico, fell into the first category, public aircraft. Because these aircraft were large, and flew at high altitudes, they carried significant risks for civilian safety. The FAA's first step toward integrating large UAS into the NAS came in September 2005, when it had issued a Memorandum, defining a process for evaluating applications for Certificates of Waiver or Authorization (COAs) for such flights (Federal Aviation Administration 2005). The document focused on safety, requiring that the operator obtain an airworthiness certificate from either the FAA or the Department of Defense. Applicants had to demonstrate that it was both unlikely and improbable that the aircraft would collide with other aircraft. The operator, referred to as the pilot in command (PIC), was responsible for the UAS. A second observer, with line of sight from either the ground or another aircraft, would serve as additional safety. Anything flying above $18,000 \mathrm{ft}$ had to be conducted under instrument flight rules (IFR) with an IFR plan, obtain air traffic control (ATC) clearance, be equipped with at least a Mode $\mathrm{C}$ transponder, operate navigation lights, and maintain communication between the PIC and the ATC. Similar requirements marked flight under $18,000 \mathrm{ft}$ as well. In the 2 years that elapsed between the Memorandum and the 2007 policy, the FAA issued more than 50 COAs (Unmanned Aircraft Operations in the National Airspace System 2007).

The second category of UAS noted in the 2007 policy, civil aircraft, incorporated a broad range of commercial vessels. Like aircraft in the public use category, civil 
UAS had to obtain an FAA airworthiness certificate, which would only be issued in what was considered an experimental category. Only a handful of such certificates existed. Applications had to include information regarding the safety of the devices, the expected time or number of flights, where the flights would take place, and detailed drawings or photographs of the aircraft (14 C.F.R. $\S \S 21.191,21.193$, 21.195 2016).

The 2007 notice created a somewhat binary world. On the one hand, hobbyists were not subject to regulation and could fly their aircraft anywhere. The FAA merely suggested that they keep their vessels $400 \mathrm{ft}$ from the ground and away from people, urban centers, and airports. On the other hand, when the government wanted to use large UAS in navigable air space, they had to apply for a COA. The commercial world encapsulated in the civil regulations was, for all intents and purposes, nonexistent. Those who wanted to experiment with developing commercial models could obtain a COA to do so, but they could not actually use civil aircraft for commercial purposes.

As technology progressed, the framework generated confusion. How should individuals view the use of UAS immediately above private property? Could a homeowner use an UAS over his own property, even if located in an urban center? Could a farmer, living on remote land, use an UAS to survey the crops or to identify funguses on outlying fields? Could she use the UAS to spray pesticides on infected plants, with significant savings for not having to spray entire fields (Cho 2014, p. 42)? These latter uses appeared to be commercial applications of UAS and thus forbidden by the notice. Despite this, many farmers began using UAS for such purposes, assuming that their actions fell within the recreational exception in the 2007 notice (Cho 2014, pp. 42-43).

The challenge, for the federal government, was how to encourage innovation and efficiency while ensuring safety. Commercial applications expanded to include everything from aerial photography and film, surveying land, and spraying crops to monitoring storms and forest fires; building bridges, towers, and buildings; and providing communications. UAS could be used for security, for disaster response, and for transporting goods. They could be used to conduct spectral and thermal analyses, or to monitor critical infrastructure, such as power lines, pipelines, ports, and energy facilities.

The FAA was aware of the need to provide a way for these industries to flourish. The Association for Unmanned Vehicle Systems International (AUVSI) predicted that the integration of UAS into the NAS would total more than $\$ 13.6$ billion for the first 3 years of integration, growing to more than $\$ 82.1$ billion between 2015 and 2025 (Jenkins and Vasigh 2013, p. 2). Their employment numbers were significant: the burgeoning UAS industry would create more than 34,000 manufacturing jobs, and more than 70,000 new jobs in the first 3 years, with the total job creation by 2025 estimated at 103,776 (Jenkins and Vasigh 2013, p. 2). AUVSI noted that the salaries for these positions would reflect the need for technical baccalaureate degrees, with an average of $\$ 40,000$ each (Jenkins and Vasigh 2013, p. 2). Based on this, the tax revenue to the states would total more than $\$ 482$ million in the first 11 years following integration (2015-2025) (Jenkins and Vasigh 2013, p. 2). More 
alarmingly, for every year that the United States delayed integration, it would cost the country more than $\$ 10$ billion (Jenkins and Vasigh 2013, p. 2).

In 2011, the FAA justified its effort to expand to take account of UAS by reference to its mission: "to provide the safest, most efficient aviation system in the world" (Federal Aviation Administration 2011a, p. 1). The FAA continued, "What sets [the United States] apart is the size and complexity of our infrastructure, the diversity of our user groups, our commitment to safety and excellence, and a history of innovation and leadership in the world's aviation community" (Federal Aviation Administration 2011a, p. 1). The organization was "working to develop new systems and to enhance a culture that increases the safety, reliability, efficiency, capacity, and environmental performance of our aviation system" (Federal Aviation Administration 2011a, p. 1). The agency was committed to integrating UAS as part of its implementation of the Next Generation Air Transportation System (NextGen) and the same year established an Unmanned Aircraft Systems Aviation Rulemaking Committee (UASARC) to do so (Federal Aviation Administration 2011b).

As it became clear that new rules were needed, Congress stepped forward. The 2012 Federal Aviation Administration Modernization and Reform Act (FMRA) passed the Senate by a wide margin ("H.R. 658 Vote Summary" 2017). Once again, there was a carve-out for hobbyists. The legislation prohibited the FAA from making any rules or regulations regarding model aircraft where flown strictly for hobby or recreational uses, the aircraft is operated in accordance with a community-based set of safety guidelines, the aircraft is less than $55 \mathrm{lb}$, it does not interfere with any manned aircraft, and, when flown within 5 miles of an airport, the operator provides ATC with prior notice of the planned flight (FAA Modernization and Reform Act of 2012, § 336(a)). The FAA Administrator may pursue action against anyone operating model aircraft when the safety of the National Airspace System is imperiled (FAA Modernization and Reform Act of 2012, § 336(b)). Visual line of sight (VLOS) must be maintained. UAS usage outside of these parameters would require FAA authorization.

The legislation tasked the government with determining how to integrate all classes of UAS into the NAS by 2015 (FAA Modernization and Reform Act of 2012, § 903). To accomplish this aim, it directed the FAA to create six sites for research and development (FAA Modernization and Reform Act of 2012, § 332). The FAA subsequently established test sites in six states: Alaska, Nevada, New York, North Dakota, Texas, and Virginia (Federal Aviation Administration 2013a). The Act required a host of reports from the FAA.

By May 2014, the FAA had issued 27 UAS-related documents (Federal Aviation Administration 2017). Most of the reports focused on FAA actions. One plan, Integration of Civil Unmanned Aerial Systems (UAS) in the National Airspace System (NAS) Roadmap, was careful to distinguish the FAA's role from that of other federal agencies; however, it paid scant attention to the role of the states.

The Executive Summary began, "A key activity of the FAA is to develop regulations, policy, procedures, guidance material, and training requirements to support safe and efficient UAS operations in the NAS, while coordinating with relevant departments and agencies to address related key policy areas of concern 
such as privacy and national security" (Federal Aviation Administration 2013b, p. 5). Thus, the FAA's role was, narrowly, to ensure safety, while other agencies could think about different policy implications. From the FAA's perspective, to the extent that privacy entered the equation, it was only in regard to civilians located in proximity to the six test sites. National security mattered only insofar as certification of UAS-related personnel, cyber and communications vulnerabilities, and maintaining/enhancing air defense and air domain awareness capabilities would exist in a complex and crowded environment (Federal Aviation Administration 2013b, p. 12).

As the FAA was only one agency in the broader question of UAS integration, the Joint Planning and Development Office (JPDO), which had been created by Congress in 2003 to coordinate NextGen among numerous entities, presented a 5year roadmap proposing how civil UAS would be integrated into the NAS (Federal Aviation Administration 2013b). One of the JPDO's first steps was reviewing how to incorporate UAS-specific changes into the NextGen Implementation Plan (Joint Planning \& Development Office 2013, p. 4).

Part of the problem was that NextGen did not have UAS as part of its remit. The approach taken by JPDO, as well as the FAA, was to look at how the technologies used in NextGen, such as the NAS voice system (NVS), would play a role in the safe integration of UAS into the NAS (Federal Aviation Administration 2014a, p. 16). Instead of creating a separate project, JPDO looked at how to expand the existing projects to take account of UAS. (For example, the NVS, secured through Voice over Intranet Protocol (VoIP), applied to both ATCs and pilots, including PICs of UAS.)

The FAA urged that the public, (read: Congress), take a longer-term perspective, consistent with the approach adopted generally by the National Aeronautics Research and Development Policy, which had been issued in 2006 to guide US aeronautics research and development programs through 2020. In its UAS roadmap, the FAA set the horizon at 2022-2026, aligning the document with the NextGen plan (Joint Planning \& Development Office 2010).

Despite the clear prohibition in the 2012 FAA Modernization and Reform Act on the FAA making any regulations outlawing hobbyist drone flights, the FAA appears to have been emboldened by the law, as it began to try to prosecute those who fell outside the guidelines. In doing so, the FAA moved onto shaky constitutional ground. While it might have the authority to regulate UAS interfering with the NAS, it did not have the authority to criminalize certain uses of UAS writ large (see discussion, infra).

UAS hobbyists were quickly outraged at the FAA's effort to regulate all flight. "How does the agency prefer you fly? For free, within line of sight, in the middle of nowhere, and very low to the ground," wrote one commentator (Koebler 2014a).

In this environment, the case of Raphael Pirker garnered particular attention. In 2011, an advertising agency had contacted Swiss photographer, Raphael Pirker (a.k.a. Trappy), to ask him to take aerial footage of the University of Virginia for use in an ad campaign (Koebler 2015; Esler 2015). Pirker used a Zephyr fixedwing small UAS (sUAS) to capture spectacular footage of the campus. In 2012, the 
FAA pursued Pirker, saying that because he got paid for the footage, his sUAS fell within the commercial aircraft category, making it illegal for him to fly it without a COA. In March 2014, however, a federal administrative law judge found in favor of Pirker, suggesting that the sUAS was not subject to the FAA rules governing manned aircraft.

The FAA appealed to the National Transportation Safety Board (NTSB), which overturned the administrative judge's decision. According to the NTSB, the statutory language defining "aircraft" included UAS. Moreover, the NTSB found that the FAA could determine when its regulation prohibiting careless or reckless operations had been violated. The case then returned to the administrative law judge to try the case, with potential appeal to the Court of Appeals. Ultimately, Pirker settled the case for $\$ 1100$ (Koebler 2015).

The issue in Pirker's case was whether sUAS should be considered aircraft. The 2012 FAA Modernization Reform Act created a "special rule for model aircraft," defining the latter as "an unmanned aircraft" that is "(1) capable of sustained flight in the atmosphere; (2) flown within visual line of sight of the person operating the aircraft; and (3) flown for hobby or recreational purposes" (FAA Modernization and Reform Act of 2012, § 336(c)).

This definition was consistent with the FAA's existing definition of aircraft as "any contrivance invented, used, or designed to navigate, or fly in, the air" (49 U.S.C. $\$ 40102$ 2016; 14 C.F.R. § 1.1 2016). However, the definition of "model" aircraft, meant to narrow the type of aircraft, fell woefully short of the technology being used. Hobbyists, at the time, for instance, were already using first-person view (FPV), which allowed the operator to see from the aircraft itself, when the aircraft was out of VLOS.

In June 2014, while the Pirker case was pending, the FAA released Further Guidance to Model Aircraft Operators, placing its interpretation of the statutory special rules for model aircraft in the Federal Register. The press release accompanying the notice put a new spin on the earlier guidelines, upgrading them to requiring compliance and asserting that hobbyists had to obey the dos and don'ts of flying safely (Federal Aviation Administration 2014b). The notice redefined what it meant by "aircraft" - ostensibly to address the legal challenge brought by Pirker, and it doubled down on the prohibition of use of FPV, the technology that was quickly taking over the hobbyist realm (Federal Register 2014).

In its June 2014 notice, the FAA took a troubling position on the extent of its powers. While the agency acknowledged that Congress had directed that the FAA may not promulgate any rule or regulation on model aircraft, it took the position that the agency could issue rules or regulations affecting model aircraft, as long as they applied to aircraft, generally. The example given was rules addressing the use of airspace. The law, the FAA claimed, did not require them to exempt model aircraft from rules applying to other aircraft where safety and security were on the line. In contrast, the FAA potentially could not apply UAS aircraft certification rules to model aircraft, because of the Congressional limitation on future rulemaking 
"regarding a model aircraft, or an aircraft being developed as a model aircraft" (Federal Register 2014).

The 2012 statute allowed the FAA to provide exemptions for sUAS for nonmodel aircraft purposes, such as the development of commercial UAS (49 U.S.C. § 44101). The FAA provided a process for obtaining permission to sidestep the rules (14 C.F.R. pt. 47 and pt. 45 2016). Over the next 4 years, the FAA issued more than 4500 exemptions authorizing operation of sUAS for non-model aircraft purposes under Section 333 of the FMRA (Registration of Small Unmanned Aircraft Systems Operated Under Exemptions Issued by the FAA 2016). In the interim, in February 2015, the FAA issued a proposed rulemaking on small UAS (sUAS). More than 4600 public comments were submitted in response. Throughout this time, the FAA continued to work on integrating UAS into the NAS.

In December 2015, the FAA and Department of Transportation (DoT) issued an Interim Final Rule establishing registration and marking requirements for sUAS that weigh more than 0.55 and less than $55 \mathrm{lb}$ (Registration and Marking Requirements for Small Unmanned Aircraft 2015, p. 78,595). It adopted a web-based registration system for sUAS and required that all aircraft, including model aircraft and that had been granted exemptions, register in accordance with the regulations.

In June 2016, the FAA issued a final rule, amending its regulations to allow the operation of sUAS in the NAS. The rule altered the operation of UAS and certification of remote pilots while prohibiting model aircraft from endangering the safety of the NAS. The final rule became effective August 29, 2016 (Operation and Certification of Small Unmanned Aircraft Systems 2016).

The goal was to enable certain sUAS operations to begin immediately and to integrate future technologies into the framework. The rule added a new Part 107 to Title 14 of the Code of Federal Regulations, to allow for routine civil operation of sUAS in the NAS. The FAA defined sUAS as unmanned aircraft weighing less than 55 pounds, restricting their flight to daytime and civil twilight, confined areas of operation, and VLOS operations. The FAA again cited safety and risks to national security as the rationale behind the regulations. An FAA airworthiness certificate was not required, although the remote PIC had to conduct a preflight check of sUAS to make sure that it was in a condition for safe operation. Part 107 required that pilots obtain sUAS certificates, based on an aeronautical knowledge test at an FAAapproved knowledge testing center, or complete a flight review within the previous 24 months and complete a small UAS online training course provided by the FAA. Pilots also had to be vetted by the Transportation Security Administration and be at least 16 years old.

While the FAA, in large part, has focused on the potential risk to the NAS should UAS operators act irresponsibly or with malice, as the Pirker case and the increasingly broad understanding of its own authority have presented, it has begun to cross into the states' domain, with significant constitutional implications. 


\section{State Laws}

Most states have taken steps to regulate UAS. Only 14 states do not have any statewide UAS laws. Numerous states, such as Alaska, California, Indiana, Louisiana, Michigan, Nevada, North Dakota, Oregon, Tennessee, Vermont, Virginia, and Wisconsin, have passed multiple measures. Like the federal government, states are acutely aware of the opportunities and risks posed by UAS. Maine articulated it thus:

The Legislature finds that evolving technology regarding unmanned aerial vehicles presents a potential economic driver for the State, an opportunity for research and development and a very real benefit for security, for search and rescue efforts and for disaster prevention and relief, as well as a tool for the investigation of serious crimes, but the technology also presents a potential threat to the privacy of citizens of this State if used by law enforcement in the conduct of criminal investigations without appropriate guidelines and supervision. (Me. Rev. Stat. Ann. tit. 25, § 4501(1) West 2016)

Because of their awareness of the many facets of UAS, states have introduced a broad range of measures, well within their constitutional bounds and in areas in which the federal government has no authority.

The definition of what, precisely, constitutes an unmanned aircraft varies by state. Some define an UAS as any aircraft capable of sustaining flight, without direct human intervention, and piloted remotely. Some specifically exclude aircraft flown in within VLOS or used for hobby or recreational purposes. Others do not. For some, the measures slot into existing aircraft provisions. For others, UAS is being treated sui generis, with entirely new rules applying to take account of the risks and potential benefits of the technology.

State UAS provisions can be divided into three categories: law enforcement, criminal law, and regulatory measures. Some states have taken the additional step of preempting local governments from introducing UAS provisions; however, others have not, with the result that cities also have introduced a range of provisions. Notably, almost all of the measures introduced by the states are well within their constitutional bounds, despite the fact that they impact UAS "from the ground up" a domain the federal government claimed in 2014, with questionable constitutional backing.

\section{Law Enforcement}

One of the most persistent concerns that states have about UAS revolves around their use by law enforcement agencies (LEAs). With privacy and property rights firmly in mind, some states initially banned LEAs from using UAS under any circumstances. In 2014, for instance, Virginia temporarily prohibited LEAs from employing UAS (Op. Att'y Gen. 2014). The following year, the state attorney general issued an opinion, noting that the Federal Aviation Act, and 2012 FMR preempted state and local regulation of UAS safety, operational standards, and airspace designations, including issues relating to UAS certification, training, and 
licensure. But the attorney general was quick to point out that there were still significant areas within which the state had primary authority:

States remain free to... regulate small drones that are exempted from federal regulations under the FMRA, and they may also enact laws for drones that address issues of privacy and property and also criminal offenses, so long as the laws do not conflict with the language or purpose of any existing federal aviation law. (Op. Att'y Gen. 2014)

Virginia, like numerous states, went on to detail when, and under what circumstances, LEAs could use UAS for surveillance.

As of the time of writing, 18 states (Florida, Vermont, Alaska, Illinois, Idaho, Indiana, Iowa, Maine, Montana, Nevada, North Carolina, North Dakota, Oregon, Tennessee, Texas, Utah, Virginia, and Wisconsin) require that law enforcement first obtain a warrant before using UAS as part of its investigatory powers. In Illinois, for instance, the Freedom from Drone Surveillance Act requires a warrant for LEA use of UAS, with a formal report of any such use due within $24 \mathrm{~h}$ and complete cessation within 48 h (725 Ill. Comp. Stat. Ann. 167/15(2), (3) West 2016). In Florida, the warrant requirement is tied to a reasonable expectation of privacy which, in contrast to federal Fourth Amendment doctrine, recognizes the importance of privacy in public space: "[A] person is presumed to have a reasonable expectation of privacy on his or her privately owned real property if he or she is not observable by persons located at ground level in a place where they have a legal right to be, regardless of whether he or she is observable from the air with the use of a drone" (Fla. Stat. Ann. $\S 934.50$ (3)(b) West 2016). If law enforcement would like to surveil a person in his or her own yard, it must first approach the courts. In Alaska, UAS can only be used with a warrant to obtain evidence in a criminal investigation or where there will be no invasion of personal privacy (Alaska Stat. Ann. § 18.65.901 West 2016).

Some states specify what must be included in the warrant application. In Nevada, the warrant must include the period of time the UAS will be used (up to 10 days), with renewal requiring a motion and further showing of probable cause (Nev. Rev. Stat. Ann. § 493.112(2) West 2015). In some states, like Idaho, it does not matter whether the person using the UAS is a government employee or not. All warrantless UAS surveillance, outside of specific circumstances, is forbidden (Idaho Code Ann. $\S 21-213(2)(a)$ West 2016).

In many states, special provision is made for exigent circumstances, as well as ordinary judicial exceptions to the warrant requirement (see, e.g., Mont. Code Ann. $\S$ 46-5-109 West 2016; Ind. Code Ann. § 35-33-5-9 West 2016; Or. Rev. Stat. Ann. $\S \S 837.310,837.320$ West 2016). In other states, such as Virginia, LEAs can bypass the warrant requirement where special circumstances hold, such as in the case of amber alerts (child abduction), senior alerts (missing seniors), and blue alerts (death or serious injury of police officers) (Va. Code Ann. § 19.2-60.1(E) West 2016).

States have put restrictions on what can be done with information legally obtained from UAS. Maine, for instance, requires that audio or visual information related to third parties be destroyed (Me. Rev. Stat. Ann. tit. 25, § 4501(5)(F) 2016). Other states, like Illinois, require the destruction of all data within a certain timeframe, unless directly pertinent to an ongoing investigation (725 Ill. Comp. Stat. Ann. 167/20(1)-(2) West 2016). 
When information is obtained outside of a warrant, most states include a suppression remedy (see, e.g., Nev. Rev. Stat. Ann. § 493.112(4) West 2015; Tenn. Code Ann. § 39-13-609(g)(2) West 2016).

In the case of LEA misuse of information obtained via UAS, some states go even further, allowing for a civil cause of action, with the possibility of recovering significant amounts of money for the dissemination of any material obtained via warrantless UAS surveillance. In North Carolina, the target can recover up to $\$ 5000$ for every photograph or video that is published or otherwise disseminated by any government employee or agency (N.C. Gen. Stat. Ann. § 15A-300.1(e) West 2016). Other states, such as Alaska, require that all images obtained by an UAS be discarded, unless directly relevant to a prosecution, to training, or to legal requirements (Alaska Stat. Ann. § 18.65.903 West 2016).

In a few states, special rules accompany certain technologies. Vermont rejects any LEA use of biometric identification technologies, such as facial recognition or iris scans (Vt. Stat. Ann. tit. 20, § 4622(d) West 2016). Next door, Maine prohibits night vision technology, video analytics, and thermal imaging, as well as biometric identification and enhanced visual aids (Me. Rev. Stat. Ann. tit. 25, § 4501(5)(D) 2016).

Almost all states that have enacted UAS laws have made special provision for LEA reporting, to ensure transparency in how the devices are being used and to help the public and the legislature in performing further oversight as the technology advances (see, e.g., Me. Rev. Stat. Ann. tit. 25, § 4501(5)(D) 2016; Nev. Rev. Stat. Ann. § 493.115 West 2015; N.D. Cent. Code Ann. § 29-29.4-06(1) West 2016; Or. Rev. Stat. Ann. § 837.360(1) West 2016; Tex. Gov’t Code Ann. § 423.008(a)-(b)(1) West 2015; Utah Code Ann. § 63G-18-105(1) West 2016).

Around half a dozen states have acted to restrict LEA weaponization of drones. Some of these states have an absolute prohibition (see, e.g., Me. Rev. Stat. Ann. tit. 25, § 4501(4)(E)-(F) 2016; Or. Rev. Stat. Ann. § 837.365 West 2016). States have further detailed different applications of UAS, such as in relation to home arrest, the documentation of crime scenes, traffic enforcement, and border searches (see, e.g., Ind. Code Ann. § 35-31.5-2-186(c) West 2016; Tex. Gov’t Code Ann. § 423.002(a)(8)(B) West 2015; Or. Rev. Stat. Ann. § 837.340 West 2016; Iowa Code Ann. § 321.492B West 2016; N.D. Cent. Code Ann. § 29-29.4-04 West 2016; Tex. Gov’t Code Ann. § 423.002(a)(1) West 2015).

\section{Criminal Law}

It is not just LEA useCriminal law of UAS that has generated increased concern. States also have paid a considerable amount of attention to the potential misuse of UAS by private actors, making a range of alterations to their criminal codes. New provisions relate to protecting emergency personnel and rescue operations, protecting private property, respecting individual privacy, preventing the weaponization of drones, regulating the use of UAS for hunting and fishing, protecting piloted airspace - as well as people and buildings on the ground - and ensuring that UAS 
is not used to threaten critical infrastructure. Like the provisions related to law enforcement, these measures are well within state authority.

\section{Emergency Personnel and Rescue Operations}

In some areas, it is illegal to use drones to interfere with emergency services. Many of these measures arise in part because of concerns about air safety - a domain claimed by the federal government but no less central to state sovereignty.

California, for example, has had long experience with UAS interference in emergency personnel's efforts to fight wildfires. Accordingly, state law forbids any UAS interference with emergency personnel, including police officers, firefighters, emergency medical, or military personnel, at the scene of the emergency (Cal. Penal Code $\S 402$ (West 2016); 2017 MT H.B. 644 (NS)). Delaware similarly makes it illegal to fly over any incident where first responders are actively engaged in response or air, water, vehicular, ground, or specialized transport, regardless of whether flying the UAS, interferes with the provision of services (Del. Code Ann. tit. 11, § 1334(b)(3) West 2016). Michigan forbids interfering with police, fire, paramedic, or search and rescue operations with an UAS (Mich. Comp. Laws Ann. § 259.321 West 2016). Louisiana prohibits crossing a police cordon, which is defined as including the airspace above the cordoned area, with an UAS (La. Stat. Ann. $\S 14: 108(\mathrm{~B})(\mathrm{e})$ 2016). In the event that an UAS in the cordoned area endangers the public or an officer's safety, law enforcement personnel or fire department personnel are authorized to disable the UAS (La. Stat. Ann. § 14:108(C) 2016). Criminal penalties of up to $\$ 500$ and 6 months' imprisonment apply (La. Stat. Ann. $\S 14: 108(C)$ 2016). Other states have similar measures (see, e.g., Mich. Comp. Laws Ann. § 259.321; Or. Rev. Stat. Ann. § 837.375 West 2016).

Complementing federal measures, some states have made it illegal to fly UAS in areas under temporary flight restrictions (TFRs) issued by the FAA in relation to wildland fires or wildland fire scenes. In July 2016, for example, Utah made it a misdemeanor, punishable by up to $\$ 5000$ fine, if the interference causes aircraft being used to control a fire to land, or to drop water or fire retardant in the wrong area, or prevents the aircraft from taking flight (Utah Code Ann. § 65A-3-2.5(3)(b) West 2016; Ariz. Rev. Stat. Ann. § 13-3729 2016).

\section{Private Property}

Numerous states have taken steps to protect private property by extending trespass laws to include the air space above the land. Louisiana, for instance, has created a statute that forbids trespass using an UAS (La. Stat. Ann. § 14:63 2016). The law defines entering upon immovable property to include operating an UAS in the air space over property owned by another, with the intent to conduct surveillance of the property or of any individual lawfully on the property (La. Stat. Ann. § 14:63(B)(2)). The statute exempts anyone operating an UAS consistent with federal guidelines as well as law enforcement officers, firefighters, and emergency medical personnel in the midst of performing their duties (La. Stat. Ann. § 14:63(E)). Fines of up to $\$ 1000$ and imprisonment of up to 6 months apply (La. Stat. Ann. § 14:63(G)). 
Oregon has a similar approach, but the state exempts inadvertent flights above others' land. Damages may only be rewarded where an operator flies over property on more than one occasion, and the individual notified the owner or operator of the UAS they did not want the UAS flown over the property (Or. Rev. Stat. Ann. $\S 837.380(1)$ West 2016). Oregon law, however, bars bringing a suit if the aircraft is in the process of takeoff or landing or if the aircraft is operated for commercial purposes in compliance with FAA authorization (Or. Rev. Stat. Ann. § 837.380(2), (3)). The attorney general of the state, though, may bring an action or claim for relief alleging nuisance or trespass related to operation of an UAS in state airspace (Or. Rev. Stat. Ann. § 837.380(6)).

Some states have set a ceiling above property, to protect against UAS use immediately above the land. In Nevada, a person who owns or occupies real property may bring an action for trespass against the owner or operator of an UAS flown at a height of less than $250 \mathrm{ft}$ over the property, where the operator has done it at least once before, and the aggrieved individual notified the operator that he did not authorize such flights (Nev. Rev. Stat. Ann. § 493.103(1) West 2015). The action cannot be brought against law enforcement or public agencies lawfully operating drones, or if the UAV is in the process of taking off or landing, or is in flight path for landing (Nev. Rev. Stat. Ann. § 493.103(2)). In California, the ceiling is set at $350 \mathrm{ft}$ (Cal. Civ. Code $\S 853$ West 2017). Tennessee's ceiling is even higher (and twice as high as Nevada) at $500 \mathrm{ft}$ (Nev. Rev. Stat. Ann. § 493.103(1) West 2015). The action cannot be brought against law enforcement or public agencies lawfully operating drones, or if the UAV is in the process of taking off or landing, or is in flight path for landing (Nev. Rev. Stat. Ann. § 493.103(2)). Employers in Tennessee can join a no trespass list, maintained by the secretary of state, to request the recognition of private property rights (Tenn. Code Ann. § 39-14-405(f) West 2016). When granted, the employer will appear on a public notice list distributed to all LEAs.

Other states have gone further than protecting the physical area of real property by creating a right of action for UAS surveillance of any property regardless of whether the aircraft enters the airspace above the owner's real property. In California, a person is liable for physical invasion of privacy when he or she

\footnotetext{
knowingly enters onto the land or into the airspace above the land of another person without permission or otherwise commits a trespass in order to capture any type of visual image, sound recording, or other physical impression of the plaintiff engaging in a private, personal, or familial activity and the invasion occurs in a manner that is offensive to a reasonable person. (Cal. Civ. Code § 1708.8(a) West 2017)
}

No physical trespass, however, must occur. It is sufficient that the image, sound recording, or other impression could not have been achieved without a trespass unless an UAS were used (Cal. Civ. Code $\S 1708.8(\mathrm{~b})$ ). Not only is the individual guilty of the invasion culpable, but any person who "directs, solicits, actually induces, or actually causes another person, regardless of whether there is an employer-employee relationship," to commit the offense, is liable for any damages resulting from the violation, as well as punitive damages (Cal. Civ. Code $\S$ 1708.8(e)). 
Similarly, North Carolina does not require entry onto the property for the offense to occur. State law prohibits any person, entity, or state agency from using UAS to conduct surveillance of a person, dwelling occupied by a person, that dwelling's curtilage, or any real property owned by an individual, without the person's consent. (N.C. Gen. Stat. Ann. § 15A-300.1(b) West 2016). Numerous states have further provisions that protect private property (see, e.g., Tenn. Code Ann. § 39-13903(a)(1), (3) West 2016; Tenn. Code Ann. § 39-13-902 West 2016; Tex. Gov't Code Ann. § 423.003(a)-(c) West 2015).

Some states, such as North Carolina, forbid using state or private property to launch UAS without the property owner's consent (N. C. Gen. Stat. Ann. § 15A300.2(a) West 2016). Others, such as Oregon, regulate model aircraft taking and landing facilities in certain areas zoned exclusively for farm use (Or. Rev. Stat. Ann. $\S 215.213$ West 2016; Or. Rev. Stat. Ann. § 215.283 West 2016).

\section{Individual Privacy}

States have introduced a range of measures to prohibit the use of UAS for voyeurism or to harass or stalk individuals.

Before UAS were commonplace, states already had statutes to prohibit photographing or recording others who might be naked or clad only in their undergarments (see, e.g., Mich. Comp. Laws Ann. § 750.539j West 2016). In most cases, these laws have been left intact. But in a handful of cases, states have amended their voyeurism laws to include committing the offense by means of an UAS (see, e.g., La. Stat. Ann. § 14:283.1(A) 2016). Other states have created new crimes of "video voyeurism" to capture untoward use of UAS (see, e.g., Ark. Code Ann. § 5-16101(a) West 2016). For some states, like Mississippi, entering onto real property (regardless of whether the entry is legal), and using UAS to record individuals without their consent, is a felony (Miss. Code Ann. § 97-29-61(1)(a) West 2017).

Other states have amended their "Peeping Tom" statutes to incorporate UAS. In Louisiana, for instance, using an UAS to look through windows, doors, or similar places on others' premises carries with it fines ranging from $\$ 500$ to 1000 , and imprisonment up to 1 year with hard labor, depending upon the number of convictions (La. Stat. Ann. § 14:284(C) 2016). Again, in recognition that UAS can be piloted remotely, the statute specifically states that it is not necessary for the person being spied upon to be present for the violation to occur. This means that individuals could potentially be located in other states but still be liable to violations of the law for UAS within state bounds. In other states, it is illegal to use UAS to harass people (see, e.g., Mich. Comp. Laws Ann. § 259.322(1) West 2016). In at least one state (Michigan), individuals already subject to the restraints included in sex offender registry are now also prohibited from operating UAS (Mich. Comp. Laws Ann. § 259.322(4) West 2016).

\section{Weaponization}

In July 2015, a teenager in Clinton, Connecticut, posted a video of an UAS equipped with a handgun, shooting objects in the woods (Smith 2016). Austin Haughwout, the young man who created the UAS, was expelled from Central Connecticut State 
University after the video went viral (currently, it has been viewed more than four million times) (The Lip TV 2016). Haughwout later designed a flame-thrower UAS which, like the gun model, appears to be perfectly legal in Connecticut.

Haughwout is far from the only person to weaponize an UAS. Numerous videos detail how to build UAS that can aim and shoot a weapon (see, e.g., LBCk2012 2016). These videos are getting enormous attention: as of the time of writing, one of them has been viewed more than 32 million times (FPSRussia 2012). Nevertheless, only five states have outlawed the practice.

Oregon was one of the first states to take a step in this direction, in 2013 prohibiting public bodies from weaponizing UAS and later extending the prohibition to any person within the state. It is now a Class A misdemeanor to intentionally, knowingly, or recklessly operate an UAS capable of firing a bullet or projectile "or otherwise operates an unmanned aircraft system in a manner that causes the system to function as a dangerous weapon” (Or. Rev. Stat. Ann. $§ 837.365$ West 2016). If an individual possesses or controls an UAS and causes, or attempts to cause, the UAS to fire a bullet or other projectile at an aircraft while the aircraft is in the air, direct a laser at an aircraft while the aircraft is in the air, or crash into an aircraft while the aircraft is in the air, it is a Class A felony (Or. Rev. Stat. Ann. § 837.995(1)). If an individual gains unauthorized control over an UAS licensed by the FAA or operated by the US Armed Forces, state law considers it a Class C felony (Or. Rev. Stat. Ann. $\S 837.995(2))$.

In 2014, North Carolina and Wisconsin followed suit (N.C. Gen. Stat. Ann. § 14-401.24 West 2016; Wis. Stat. Ann. § 941.292 West 2016). In North Carolina, it is a Class E felony for any person to possess or use an UAS with a weapon attached (N.C. Gen. Stat. Ann. § 14-401.24 West 2016). In Wisconsin, operating a weaponized UAS is a Class H felony (Wis. Stat. Ann. § 941.292 West 2016).

Nevada was the next state to ban weaponized UASs, introducing new measures in 2015. As in the early twentieth century, when the federal government began to introduce provisions to promote piloted aircraft safety, part of the rationale in Nevada appears to be to protect the nascent UAS industry. As Las Vegas Assemblyman Elliot Anderson noted, “There's one thing that I think makes people recoil the most: they see those drone-firing videos and they want part in it." $\mathrm{He}$ explained, "[t]he goal behind prohibiting weaponizing UAS was to make people comfortable with the industry and to make it prosper" (Smith 2016). Nevada has numerous UAS companies headquartered in state, and the Office of Economic Development is making a push to attract yet more. The state website explains,

\footnotetext{
If you are involved in the UAV industry, you've got to consider Nevada. If you are looking for the ideal location for your R\&D and testing, we're it. No other state can compare. If you are already a manufacturer involved in the industry, Nevada will be an excellent home for your expansion, where you can be nearer to testing locations. (Nev. Governor's Off. Econ. Dev. 2012)
}

Nevada has a strong aviation presence, with Creech Air Force Base, Nellis Air Force Base, a Naval Air Station, Fallon Municipal Airport, Nevada National Security Site, Reno-Stead Airport, and Boulder City Municipal Airport. The state claims to be "[t]he birthplace of the UAV Industry," home of the industry's first Center of 
Excellence, and the first state to integrate the National Guard into an UAS program (Nev. Governor's Off. Econ. Dev. 2012). It also boasts more DoD UAV pilots than any other state. Nevada's UAS statute forbids either weaponizing an UAS or operating a weaponized UAS (Nev. Rev. Stat. Ann. § 493.106(1) West 2015). It is a Class D felony simply for owning or operating one and a Class C felony if the weapon is discharged (Nev. Rev. Stat. Ann. § 493.106(1), (2)).

Most recently, in 2016, Vermont made it illegal to weaponize or equip a drone with the ability to fire a projectile (Vt. Stat. Ann. tit. 13, § 4018 West 2016). Violation carries with it up to a year in prison and a fine of up to $\$ 1000$ (Vt. Stat. Ann. tit. 13, § 4018 West 2016).

\section{Hunting and Fishing}

State hunting statutes involving UAS emerged between 2013 and 2017. More states prohibit using UAS to hunt game than do states that outlaw weaponization of UAS in general. Measures are found in state legislation, as well as in regulations issued by fishing and wildlife departments. In 2013, when People for the Ethical Treatment of Animals (PETA) and other environmental groups announced their intent to use UAS to hassle hunters and fishermen, to record potential violations of the law, and to drive game away, states also began introducing provisions to prohibit individuals from using UAS to record, observe, or interfere with hunting and fishing.

\section{Preventing the Use of UAS for Hunting or Fishing}

A number of states have amended laws that previously prohibited the use of vehicles and technology, to include UAS among prohibited devices for hunting, fishing, and trapping. For the most part, the impetus appears to come from not wanting to give hunters an unfair advantage over wildlife.

In North Carolina, it is a Class 1 misdemeanor for any person to fish or hunt using an UAS (N.C. Gen. Stat. Ann. § 14-401.24(b) West 2016). Michigan also outlaws UAS to take game (Mich. Comp. Laws Ann. § 324.40111c(2) West 2016). The statute includes in its definition both devices that use aerodynamic forces to achieve flight, as well as devices that operate on the surface of water or underwater (Mich. Comp. Laws Ann. § 324.40111c(2) West 2016).

Some state prohibitions are tailored to the established hunting season for certain species. In March 2016, for example, Indiana made it illegal to use UASs to assist in killing an animal (Ind. Code Ann. § 14-22-6-16 West 2016). The ban operates from 14 days prior to the hunting season opens for an animal species and ends with the end of the season. UASs also may not be used to search for, scout, locate, or detect a wild animal, or help to kill an animal, during its hunting season (Ind. Code Ann. $\S$ 14-22-6-16 West 2016). There is an exception for using UAS to provide veterinary treatment to wild animals (Ind. Code Ann. § 14-22-6-16(a)).

Also in 2016, Idaho outlawed use of UAS to molest, stir up, rally, or drive game animals or birds in a particular direction (Idaho Code Ann. § 36-1101(b)(2) West 2016). The state forbids using UAS to spot or locate game animals, game birds, or furbearing animals from the air or to communicate the location of the animals to persons on the ground (Idaho Code Ann. §36-1101(b)(3)). For big game, UAS can 
be used to spot herds or their location, as long as they are not hunted on the same day that they are spotted by the UAS (Idaho Code Ann. § 36-1101(b)(5)).

These measures are consistent with Idaho's general code, which prevents hunters from taking advantage of other technologies, such as motorized vehicles, helicopters, and artificial light (Idaho Code Ann. § 36-1101(b)(6)). Idaho also prohibits shooting or killing any bird or animal in Idaho, wild or domestic, with any gun or other device controlled through an Internet connection (Idaho Code Ann. § 36-1101(b)(9)). There are exceptions to some of the prohibitions for certain animals. UAS, for instance, can be used to control wolves or predatory animals, when deemed necessary by federal or state agencies, in accordance with existing management plans (Idaho Code Ann. § 36-1101(b)(5)).

West Virginia has made it unlawful to hunt, take, kill, wound, or shoot at wild animals or birds from an UAS or to use one to assist in hunting (W. Va. Code Ann. $\S$ 20-2-5(4)-(5) West 2016). It appears to be the state's only law that has been enacted in relation to UAS.

Prohibitions on the use of UAS to hunt or fish are not always at the level of state legislation. Some states have introduced rules through state agencies. In May 2015, for instance, the New Hampshire state Fish and Game Department banned the killing of wildlife using an UAS (Portland Press Herald 2015). The rules similarly prohibit the use of weapons that contain computers to lock in a target, adjust for wind or target movement, and automatically fire (Portland Press Herald 2015). Hunters may not use cameras that transmit real-time images to cellphones or computers, as a means of locating wildlife (Portland Press Herald 2015). Fish and Game Law Enforcement Major Kevin Jordan explained, "We needed to establish rules regarding these fast-changing technologies to make sure that people understand that their use for hunting is not appropriate or ethical" (Portland Press Herald 2015). He continued, "Use of this equipment violates the principle of fair chase because it gives hunters an unfair advantage over wildlife" (Portland Press Herald 2015). Similarly, in Maine, the Department of Inland Fisheries \& Wildlife forbids the use of drones to assist in hunting deer, bear, or moose (Maine, Dep't of Inland Fisheries $\&$ Wildlife 2017). Oregon required its State Fish and Wildlife Commission to adopt rules prohibiting the use of drones for angling, hunting, or trapping (Or. Rev. Stat. Ann. § 498.128(1)(a)-(d) West 2016).

Some states are also considering measures that would prohibit the use of unmanned aircraft systems to harass livestock as well. See, e.g., 2017 UT H.B. 217 (NS).

\section{Preventing the Use of UAS to Interfere in Hunting and Fishing}

In 2013, PETA announced that it had developed an "Air Angel" UAS to allow activists to monitor hunters (Mullins 2013; PETA 2013). Almost immediately, and before any complaints had been received, states began introducing measures to prevent activists from hassling people lawfully hunting and fishing.

Illinois, for instance, forbids using an UAS to interfere with another person's lawful taking of wildlife or aquatic life (720 Ill. Comp. Stat. Ann. 5/48-3 West 2016). The law defines "drone" broadly, as "any aerial vehicle that does not carry 
a human operator" (720 Ill. Comp. Stat. Ann. § 5/48-3(b)(10)). Although the Michigan Department of Natural Resources had not received a single complaint, Michigan passed a similar measure, making it illegal to harass anyone who is hunting (Mich. Comp. Laws Ann. § 324.40111c(2) West 2016). North Carolina, Wisconsin, and Oregon did the same (N.C. Gen. Stat. Ann. § 113-295 West 2016; Wis. Stat. Ann. § 29.083 West 2016; Or. Rev. Stat. Ann. § 498.128(1)(e) West 2016).

In July 2014, Tennessee made it a misdemeanor to use an UAS to interfere with the lawful taking of a wild animal (Tenn. Code Ann. § 70-4-302(a)(1) West 2016). The state also outlawed entering or remaining upon either public or private lands, without permission, with the intent to use UAS to interfere with the taking of wild animals, as well as merely conducting video surveillance of private citizens who are lawfully hunting or fishing without first obtaining their written consent (Tenn. Code Ann. § 70-4-302(a)(4), (a)(6)).

New Hampshire passed a law that went beyond just preventing individuals from using UAS to interfere with hunting, fishing, or trapping. It also made it illegal to disturb wild animals with the intent to prevent their lawful takings, as well as to conduct video surveillance of private citizens who were hunting, fishing, or trapping, without first obtaining their written consent (N.H. Rev. Stat. Ann. § 207:57(1) 2016).

Perhaps the most extreme response to the perceived threat of interference from UAS came not at a state, but at a local level. Deer Trail, Colorado, considered, but ultimately rejected, a provision that would have provided licenses to hunt UAS, turning the paradigm on its head (Steinmetz 2014).

\section{Reckless Endangerment}

UAS endangerment statutes take two forms at a state level: those seeking to secure piloted flights, and those focused on buildings and people on the ground. In the first category, although the federal government claims that its responsibility is to ensure the safety of the NAS, some states have also criminalized interference with piloted flight. In North Carolina, any person who willfully interferes with manned aircraft using UAS, while the manned aircraft is taking off, in flight, or otherwise in motion, is guilty of a Class H felony (N.C. Gen. Stat. Ann. § 14-280.3 West 2016). Oregon has criminalized any UAS interference with aircraft. The state has further provision to make it a Class A violation where the UAS is not just directing a laser at the aircraft while it is in the air, or crashing into the aircraft while it is airborne, but also preventing takeoff or landing (Or. Undesignated Enactments Ch. 72, § 5 West 2016).

The second form that statutes take is in relation to endangering buildings and people on the ground. This concern has been augmented by cases of UASs crashing into buildings. In May 2014, for instance, the New York City Police Department arrested David Zablidowsky after his UAS flew into a building in Manhattan (Koebler 2014b).

Arizona code addresses this concern by making careless or reckless use of UAS, a Class 1 misdemeanor (Ariz. Rev. Stat. Ann. § 28-8280 2016). Nevada, which includes UAS in its definition of aircraft, has made it illegal to do acrobatics or to drop any objects in heavily populated area or public gathering (Nev. Rev. Stat. Ann. 
$\S 493.020$ West 2015 (defining UAV as aircraft); Nev. Rev. Stat. Ann. § 493.100 West 2015 (making reckless flight a misdemeanor)). The state has carved out a special exception for UAS pilots in parks, who can do acrobatics as long as they do not do so "with reckless disregard for the safety of other persons and with willful indifference to injuries that could reasonably result from such operation" (Nev. Rev. Stat. Ann. § 493.100 West 2015).

One state, Nevada, outlaws flying an UAS while drunk or intoxicated (Nev. Rev. Stat. Ann. § 493.130 West 2015).

A number of cities and municipalities have passed special ordinances in regard to special events. Delaware has introduced a statewide provision. The state has passed a blanket prohibition, making it illegal to fly UAS over any sporting, concert, automobile race, festival, or other event at which more than 1500 people are in attendance" (Del. Code Ann. tit. $11 \S$ 1334(b)(1) West 2016).

\section{Critical Infrastructure}

Commentators have become increasingly concerned about the threat posed by UAS to the critical infrastructure. Airports are one of the most obvious concerns, and, because of this, the federal government has instituted requirements. However, energy plants, and especially nuclear plants, raise further concerns. This issue came to public attention in 2014, when the French government noted that there had been unexplained UAS flights over 13 of the country's 19 nuclear power plants (Lichfield 2014). The following year, UAS carrying radiological material targeted government buildings in Japan (BBC News 2015). These incidents, and the risks posed by UAS, prompted eight states to take steps to protect critical infrastructure facilities. Along with these provisions, a number of states have introduced new laws in relation to UAS near prisons.

Each state defines what it means by "critical infrastructure" differently, with implications for which buildings are protected. In Arizona, critical facilities include petroleum or alumina refineries, chemical processing or manufacturing facilities, water and wastewater treatment facilities, electric generation facilities and substations, electrical transmission lines of at least $69,000 \mathrm{~V}$, electronic communications station or towers, facilities distributing natural gas, railroad facilities, federal, state, county, or municipal courts, public safety facilities, jails, prisons, military installations, and hospitals receiving air ambulance services (Ariz. Rev. Stat. Ann. $\S 13-3729$ (F)(3) 2016). The state makes it unlawful to use UAS "to intentionally photograph or loiter over or near a critical facility in the furtherance of any criminal offence" (Ariz. Rev. Stat. Ann. § 13-3729(B) 2016). Stiff penalties apply, as loitering over a critical facility is considered a felony (Ariz. Rev. Stat. Ann. § 133729(E)).

Arkansas makes it illegal to use UAS to monitor electrical power generators, petroleum refinery, chemical or rubber manufacturing facilities, or petroleum or chemical storage facilities (Ark. Code Ann. § 5-60-103(a)(1), (b) West 2016). As for criminal penalties, the first offense counts as a Class B misdemeanor, with the second or subsequent offenses increased to a Class A misdemeanor (Ark. Code Ann. $§ 5-60-103(d))$. The state provides a civil remedy for the owner of the critical 
infrastructure that is the subject of the violation, amounting to actual damage as a result of the violation, or $\$ 10,000$ (whichever is greater), and three times actual damages, or $\$ 10,000$ (whichever is greater), where the violation resulted in monetary gain (Ark. Code Ann. § 16-118-111 West 2016).

In Delaware, it is illegal to fly over petroleum or chemical facilities, fuel storage facilities, electric substations, power plants, electric generation facilities, military facilities, commercial port and harbor facilities, rail yard facilities, drinking water treatment or storage facilities, government buildings, and public safety buildings or facilities (Del. Code Ann. tit. $11 \S 1334(a)(2)$, (b)(2) West 2016).

Louisiana makes it unlawful to use UAS to conduct surveillance on facilities without the prior written consent of the owner (La. Stat. Ann. § 14:337 2016). It excludes UAS used by state government or a local government LEA or fire department (La. Stat. Ann. § 14:337(B)(4)(c)-(d) 2016). The definition of a targeted facility centers on critical infrastructure operations, such as petroleum and alumina, chemical and rubber manufacturing, and nuclear power electric generation (La. Stat. Ann. § 14:337(B)(3) 2016).

Nevada makes it illegal to operate an UAS within $500 \mathrm{ft}$ of a critical facility or within 5 miles of an airport, unless the operator has obtained permission either from the airport or the FAA (Nev. Rev. Stat. Ann. § 493.109 West 2015).

Oklahoma has broadly defined critical infrastructure to include not just the traditional petroleum refineries, electrical power generators, natural or liquid gas facilities, and chemical manufacturing but also water treatment facilities, telecommunications central switching offices, wireless telecommunications infrastructure (including cell towers), and television and radio transmission stations (Okla. Stat. Ann. tit. 3, § 3422(A) West 2016). Unmanned aircraft are forbidden from flying over the facilities less than $400 \mathrm{ft}$ above the ground. They may not make contact with the facility or come within a distance close enough to cause a disturbance to the facility (Okla. Stat. Ann. tit. 3, § 3422(B)).

Like Oklahoma, Oregon broadly defines critical infrastructure to include traditional categories as well as telecommunications switching offices, dams, and pipelines (Or. Undesignated Enactments ch. 72, § 13(1) West 2016). Oregon also puts a 400 foot ceiling above the facilities and prohibits any contact with the structure. (Or. Undesignated Enactments ch. 72, § 13(2)). The federal government, public bodies, LEAs, and those with prior written consent of the owner are exempt (Or. Undesignated Enactments ch. 72, § 13(3)).

It is illegal in Texas to fly UAS over critical infrastructure facilities that are enclosed by fences, designed to exclude intruders, or clearly marked with signs (Tex. Gov't Code Ann. § 423.0045(a)(1) West 2015). State law also defines the types of facilities, ranging from petroleum, electrical, chemical, and gas to telecommunications, transmission stations, steelmaking, and dams (Tex. Gov't Code Ann. § 423.0045 West 2015). As in Oklahoma and Oregon, UAS cannot be flown under $400 \mathrm{ft}$ above such facilities, nor may they make contact with them, nor come close enough to interfere with their operations (Tex. Gov't Code Ann. § 423.0045(b) West 2015). In January 2016, California added schools to their sphere of protection. 
Prisons, also, have become the subject of greater state regulation. By 2016, UAS had become the hot new way to smuggle contraband into prisons (Kelly 2016). In Ohio, one prison yard became a free-for-all after an UAS dropped drugs over the prison. According to the Ohio Department of Rehabilitation and Correction, following the drop, 75 inmates gathered and a fight broke out (Ferrignno 2015). In South Carolina, regular deliveries of cell phones and contraband into Lee Correctional Institute raised officers' concerns (Schmidt 2015). In Maryland, an attempt to fly narcotics, marijuana, pornographic videos, tobacco, a cellphone, and a charger over prison walls was disrupted (Dishneau 2016). As this concern has increased, five states, California, Delaware, Oregon, Tennessee, and Wisconsin, have taken steps to make overflights illegal (Del. Code Ann. tit. $11 \S$ 1334(a)(2), (b)(2) West 2016; Or. Undesignated Enactments ch. 72, § 13 West 2016; Wis. Stat. Ann. § 114.045 West 2016; Tenn. Code Ann. § 39-13-903(a)(5) West 2016). Wisconsin further provides that any images captured may be seized by law enforcement (Wis. Stat. Ann. $\S$ 114.045(3) West 2016).

\section{Regulatory Regimes}

A range of regulatory measures have been introduced at a state level. They range from rules regarding takeoff and landing, agricultural operations, and taxes to training and certification, research and mapping, and the establishment of study groups.

Although the FAA has tried to gain greater control over the use of UAS for agricultural operations, one state regulates this area, arguably on strong constitutional grounds: in Louisiana, it is legal for private landowners engaged in agricultural commercial operations on their private property to use UAS on their property (La. Stat. Ann. $\S \S 3: 41-48$ 2016). State law requires a license from the department, once the applicant has completed an agricultural education and safety training course administered by the Louisiana Cooperative Extension Service or the Southern University Agricultural Research and Extension Center, as well as any other licensing requirements established by the Louisiana commissioner of agriculture and forestry (La. Stat. Ann. $\$ 3: 43$ (A) 2016). The licenses are good for 3 years (La. Stat. Ann. § 3:43(C) 2016). Pilots must also register their drones with the Department of Agriculture and Forestry (La. Stat. Ann. § 3:43(B) 2016).

The data obtained from such drone flights can only be used in relation to an agricultural commercial operation or in conjunction with an agricultural research, extension program, or initiative conducted by a state postsecondary school (La. Stat. Ann. $\S 3: 44(B)(3)$ 2016). In any event, all information obtained is to remain the property of the legal owner of the property where the data was collected, unless written approval is provided by the owner for other uses of the information (La. Stat. Ann. $\S 3: 44(B)(4)$ 2016). Penalties, in the form of fines, apply (La. Stat. Ann. $\S 3: 47$ 2016).

Some states have begun to take account of UAS in their tax laws. In Kansas, amateur-built aircraft, which includes unmanned aircraft, the major portion of which 
has been fabricated and assembled for education or recreational purposes, is exempt from all property or ad valorem taxes (Kan. Stat. Ann. § 79-220 West 2016). Nevada also provides partial abatement of certain taxes on unmanned aircraft. New York defines general aviation aircraft, for certain tax purposes, as not including unmanned aerial vehicles or drones (Nev. Rev. Stat. Ann. § 360.753 West 2015). Pennsylvania, in contrast, for tax purposes, considers "aircraft" to include unmanned aircraft (72 Pa. Stat. and Cons. Stat. Ann. § 7201 West 2016). This exempts UAS retail sales or services from certain taxes (72 Pa. Stat. and Cons. Stat. Ann. § 7204(69) West 2016).

Although the federal government claims jurisdiction over pilot training, three states, in addition to Louisiana (see discussion, supra, regarding agriculture), have special training and certification programs. Alaska, for example, has directed the University of Alaska to establish a training program in the operation of UAS (Alaska Stat. Ann. § 14.40.082 West 2016). North Carolina similarly has directed its Department of Transportation to develop a test for operating UAS that complies with federal and state law, ensuring that drone operators know the applicable rules (N. C. Gen Stat. Ann. § 63-95 West 2016). The state lays out its own criteria for operating commercial UAS, which go beyond the federal requirements: pilots must be 17 years old, possess a valid drivers' license, pass the knowledge test for operating UAV, and satisfy a number of other requirements (N. C. Gen Stat. Ann. § 63-96 West 2016). Maine similarly requires that law enforcement undergo special training and certification prior to using UAVs (Me. Rev. Stat. Ann. tit. 25, §4501(5) 2016).

Numerous states allow for law enforcement to operate UAS without a warrant for training purposes. Almost all which do so simultaneously prohibit using any image or other information obtained during training in court or using it to establish reasonable suspicion or probable cause (see, e.g., Or. Rev. Stat. Ann. § 837.345 West 2016).

States also are making provision for rules governing the flying of drones in public parks (see, e.g., Haw. Code R. § 15-210-13 2017).

Many states exempt research institutions from the laws restricting drone use, on the condition that any images obtained in research be used solely for the purpose for which they were collected, and not for law enforcement purposes. In Texas, for instance, it is lawful to capture images (broadly defined as including any electromagnetic signals, sound waves, light waves, etc.) "for the purpose of professional or scholarly research and development or for another academic purpose." Similarly, almost all states exempt drone use for surveying or mapping (Tex. Gov't Code Ann. §§ 423.001, 423.002(a)(1) West 2015).

Some states kick the decision of what rules should govern drones to entities within the state. Hunting, discussed above, provides one such example. Another is in relation to state buildings. In Texas, for instance, the director of the Department of Public Safety is responsible for adopting rules concerning UAS in the Capitol Complex (Tex. Gov't Code Ann. § 411.062 West 2015). For law enforcement, the responsibility falls to the Department of Public Safety (Tex. Gov't Code Ann. § 423.007 West 2015). 
Finally, it is worth mentioning that some states are not quite sure what to do about UAS, and so they have formed study groups (see, e.g., Md. Code Ann., Econ. Dev. § 14-301 note West 2016). In 2015, for instance, Illinois created an unmanned aerial system task force to consider the operation, use, and regulation of UAS within the state (20 Ill. Comp. Stat. Ann. 5065/1 to 5065/99 West 2016). The membership of the task force reflected the myriad concerns raised by drone technology: it included, inter alia, representatives from the Division of Aeronautics of the Department of Transportation, the Department of State Police, the Department of Natural Resources, the Department of Agriculture, and the Department of Commerce and Economic Opportunity (20 Ill. Comp. Stat. Ann. § 5065/15(b)(1)-(5) West 2016). Other members included an UAS technical commercial representative, an UAS manufacturing industry representative, a person nominated by the attorney general, a member of the Illinois Conservation Police Lodge, and representatives of a series of statewide associations, including a sportsmen's federation, agricultural association, commerce association, electric utility, retail association, manufacturing trade association, property and casualty insurance association, real estate brokers association, and surveying association (20 Ill. Comp. Stat. Ann. § 5065/15(6)-(13), (15)-(19) West 2016). Various others, ranging from the National Guard and police from a major metropolitan area to railroads and broadcasters, were also included (20 Ill. Comp. Stat. Ann. § 5065/15(b)(1), (20)-(23) West 2016). Illinois directed the task force to consider commercial and private uses of drones, landowner and privacy rights, and general rules and regulations for the safe operation of drones (20 Ill. Comp. Stat. Ann. $\S 5065 / 15$ (e) West 2016). The final report was due to the Governor and General Assembly no later than July 1, 2017 (20 Ill. Comp. Stat. Ann. $\S 5065 / 15(\mathrm{~g})$ West 2016).

Michigan, in turn, has formed a task force to develop statewide policy recommendations on the operation, use, and regulation of UAS (Mich. Comp. Laws Ann. § 259.331(1) West 2016). The task force included individuals from the Department of Transportation (bridges and road work), Department of State Police, Department of Natural Resources, Department of Agriculture and Rural Development, Department of Licensing and Regulatory Affairs, and Department of Corrections (Mich. Comp. Laws Ann. § 259.331(2)(a)-(g) West 2016). State law required also representatives from a wide range of groups, such as industry, a licensed pilot under the FAA civil aircraft code, airport representatives, local law enforcement, agriculture, retail, manufacturing, insurance, real estate, surveyors, and railways (Mich. Comp. Laws Ann. § 259.331(2) West 2016). The appointments are for 4 year terms, with all meetings public (Mich. Comp. Laws Ann. § 259.331(4), (9) West 2016). The task force's goal is to consider commercial and private uses of UAS, landowner and privacy rights, and general rules and regulations for safe operation of UAS (Mich. Comp. Laws Ann. § 259.331(12) West 2016). 


\section{Constitutional Powers}

The explosion in state UAS laws reflects the fact that, since the Founding, states have possessed broad authority to govern their internal affairs. Their authority extends to persons and land within state boundaries. Federal sovereignty as it relates to UAS extends only as far as interstate commerce and matters of national defense. When legislation introduced under these powers comes into conflict with state law, under certain circumstances, state provisions may be preempted. But even here, as the history of aviation illustrates, there are limits on what the federal government can do.

\section{Dual Sovereignty}

From the country's inception, states have had a tremendous amount of authority separate from and outside federal power. The Articles of Confederation recognized that each state retained "its sovereignty, freedom, and independence, and every Power, Jurisdiction and right, which is not by this confederation expressly delegated to the United States, in Congress assembled" (Articles of Confederation, Art. II). States had so much independence, that the confederation itself teetered on the brink of failure. But when delegates assembled in Philadelphia in 1787 for the Constitutional Convention, even as they strengthened the national government, they preserved state sovereignty as a check on federal power.

Not everyone was convinced that the delegates had gone far enough to assuage concern. James Madison answered the anti-federalist claim that the new government would threaten state sovereignty. "The State governments," he wrote, "may be regarded as constituent and essential parts of the federal government; whilst the latter is nowise essential to the operation or organization of the former" (Madison $1788 / 1961$ b, p. 291). Each branch would "owe its existence more or less to the favor of the State governments, and must consequently feel a dependence, which is much more likely to beget a disposition too obsequious than too overbearing towards them" (Madison 1788/1961b, p. 291). In contrast, the states would not be indebted to the federal government. States also would be wealthier. (It was not until the 16th Amendment passed and was ratified in 1913 that Congress gained the power to lay and collect income tax.) The danger was not that the federal government would be too powerful but that state governments would dismantle the nascent national one. Alexander Hamilton (1787/1961) explained:

\footnotetext{
Whoever considers the populousness and strength of several of these States singly at the present juncture and looks forward to what they will become, even at the distance of half a century, will at once dismiss as idle and visionary any scheme which aims at regulating their movements by laws to operate upon them in their collective capacities and to be executed by a coercion applicable to them in the same capacities. (p. 115)
}

Union would guard against state aggression, faction, and insurrection. But while a stronger national government was necessary, even then, it was subject to constraints that preserved state sovereignty. 
The new Constitution went on to recognize state power in numerous ways. For one, it restricted the authorities granted to the federal government. This meant that the national government would be one of limited powers, while states would enjoy broader authority. Madison (1788/1961a) explained,

The powers delegated by the proposed Constitution to the federal government are few and defined. Those which are to remain in the State governments are numerous and indefinite. The former will be exercised principally on external objects, as war, peace, negotiation, and foreign commerce... The powers reserved to the several States will extend to all the objects which, in the ordinary course of affairs, concern the lives, liberties, and properties of the people, and the internal order, improvement, and prosperity of the State. (pp. 292-293)

Article I, $\S 8$ listed 18 areas in which the federal government could act. Outside of these areas, Congress did not possess any power. It fell to the states to protect the lives, liberties, and property of the people.

Even within the enumerated powers, the Constitution recognized state authority. In establishing the seat of government, Article I, $\S 8$, cl. 17 granted Congress the power:

To exercise exclusive Legislation in all Cases whatsoever, over such District (not exceeding ten Miles square) as may, by Cession of particular States, and the Acceptance of Congress, become the Seat of the Government of the United States, and to exercise like Authority over all Places purchased by the Consent of the Legislature of the State in which the Same shall be, for the Erection of Forts, Magazines, Arsenals, dock-Yards, and other needful Buildings. (U.S. Const. art. I, § 8, cl. 17)

This clause underscored that the states retained full control over their territory. Congress lacked jurisdiction within state bounds.

The impetus behind the clause was clear: while some provision had to be made for the federal government to acquire property - thus filling a gap in the Articles of Confederation - the national government's ability to do so was premised upon state sovereignty. Madison (1788/1961a) wrote,

[The federal district is] to be appropriated to this use with the consent of the State ceding it; as the State will no doubt provide in the compact for the rights and the consent of the citizens inhabiting it; . . . as they will have had their voice in the election of the government which is to exercise authority over them; . . . as the authority of the legislature of the State, and of the inhabitants of the ceded part of it, to concur in the cession will be derived from the whole people of the State in their adoption of the Constitution, every imaginable objection seems to be obviated. (pp. 272-273)

The national government had no power over land within state bounds. It was only through local, democratic mechanisms that a state could cede territory to it.

In further recognition of the two sovereigns, the Constitution forbade the federal government from appropriating state territory without the consent of the citizens of that state. This did not mean that new states could not be added to the union (they could); however, "no new states shall be formed or erected within the jurisdiction of any other state; nor any state be formed by the junction of two or more states, or parts of states, without the consent of the legislatures of the states concerned..." (US Const. art. IV, $\S 3$ ). 
The Guarantee Clause went on to explicitly recognize state sovereignty: "The United States shall guarantee to every State in this Union a Republican Form of Government, and shall protect each of them against Invasion; and on Application of the Legislature, or of the Executive (when the Legislature cannot be convened), against domestic violence" (US Const. art. IV, § 4). The clause acknowledged that the states were republics in their own right. The only time that the federal government could step in was in the case of invasion or when the states requested assistance through their democratic branches. And throughout the Constitution, the text referred to "citizens" of the states, such as in relation to the judicial power and the privileges and immunities. See, e.g., US Const. art. IV, $§ 2$.

Perhaps most importantly, the Tenth Amendment acknowledged that all powers not delegated to the federal government, nor prohibited to the states by the Constitution (such as those relating to war), would be reserved to the states (US Const. amend. X). The powers to which this clause referred were extensive. They included police powers - traditionally understood as laws relating to the health, welfare, and morals of the population. To states fell the power to enact criminal law, to redress environmental concerns, and to charter corporations. States had authority over education, manufacturing, and agriculture. They were responsible for regulating, controlling, and governing real and personal property, as well as individuals within state borders. The Supreme Court later explained,

\footnotetext{
Although this court has refrained from any attempt to define the limits of [state police powers], yet it has distinctly recognized the authority of a state to enact quarantine laws and health laws of every description; indeed, all laws that relate to matters completely within its territory and which do not by their necessary operation affect the people of other states. (Jacobson v. Massachusetts 1905, p. 25 (internal quotes omitted))
}

A dozen years later, the Court again acknowledged that while it had not tried to define police powers, "its disposition is to favor the validity of laws relating to matters completely within the territory of the state enacting them" (Thomas Cusack Co. v. City of Chicago 1917, p. 531 (emphasis added)). A broad understanding of state authority, and deference to state law, marked the judicial realm.

\section{State Jurisdiction over Persons and Land}

Recognition of state sovereignty extends to questions of jurisdiction, where the courts have repeatedly come down in support of state rights.

In 1790, Congress attempted to outlaw murder or robbery committed "upon the high seas or in any river, haven, basin or bay, out of the jurisdiction of any particular state" (Act of Apr. 30, 1790, ch. 9, § 8). The act lay untouched for a quarter of a century, until it was used to prosecute William Bevans, a marine on board the US warship Independence, who murdered the cook's mate, while the ship was lying at anchor in Boston Harbor. The Supreme Court objected: "Congress may pass all laws which are necessary and proper for giving the most complete effect to [the exercise of admiralty and maritime jurisdiction granted to the government of the union.] 
Still, the general jurisdiction over the place, subject to this grant of power, adheres to the territory, as a portion of territory not yet given away. The residuary powers of legislation are still in [the state)" (United States v. Bevans 1818, p. 389 (emphasis added)). State sovereignty was so strong that federal authority only extended to land within its exclusive power.

Decisions by state courts underscored the primacy afforded matters within their bounds. The same year that Bevans was handed down, the Supreme Court of Pennsylvania attributed to Art. I, $\S 8$, cl. 17 recognition that "The legislative power and exclusive jurisdiction remained in the several states, of all territory within their limits, not ceded to, or purchased by, congress, with the assent of the state legislature, to prevent the collision of legislation and authority between the United States and the several states" (Commonwealth v. Young 1818, p. 309).

In 1837, the Supreme Court acknowledged the extent of state powers:

[A] State has the same undeniable and unlimited jurisdiction over all persons and things, within its territorial limits, as any foreign nation; where that jurisdiction is not surrendered or restrained by the Constitution of the United States. . . . [B]y virtue of this, it is not only the right, but the bounden and solemn duty of a State, to advance the safety, happiness and prosperity of its people, and to provide for its general welfare. . [A]ll those powers which relate to merely municipal legislation, or what may, perhaps, more properly be called internal police, are not thus surrendered or restrained; and that, consequently, in relation to these, the authority of a State is complete, unqualified and exclusive. (New York v. Miln 1837, p. 139)

States retained jurisdiction over persons and things within their bounds, as well as the right to legislate for the safety, happiness, and prosperity of their citizens.

Even where the federal government had certain, limited rights, states remained sovereign. In 1845, the Supreme Court considered a statutory provision upon which Alabama's admission to the union had been premised: "[A]ll navigable waters within the said state shall forever remain public highways, free to the citizens of said state, and of the United States, without any tax, duty, impost, or toll therefor [sic.] imposed by said State" (Act for the Admission of Alabama 1819, §6, 3).

While upholding the clause, the Court was careful to recognize state sovereignty: "No principle is more familiar than this," the Court wrote, "that whilst a state has granted a portion of its sovereign power to the United States, it remains in the enjoyment of all the sovereignty which it has not voluntarily parted with" (Pollard v. Hagan 1845 , p. 216). The statutory provision did not deprive the state of its rights over navigable waters; nor did it affect state control over the shores or the soil under the navigable waterways. "[T] he United States never held any municipal sovereignty, jurisdiction, or right of soil in and to the territory, of which Alabama or any of the new States were formed," the Court explained (Pollard v. Hagan 1845, p. 221). Alabama, therefore, was "entitled to the sovereignty and jurisdiction over all the territory within her limits, subject to the common law" (Pollard v. Hagan 1845, p. 222).

The entire doctrine of federal jurisdiction is rooted in the premise that states control property and people within their bounds. As Lowell Becraft, a constitutional attorney in Alabama, has explained, over time, the doctrine has changed only at 
the margins and in a direction extending greater control to states, allowing them to retain jurisdiction over partially ceded territory: "[W] hat was definitely decided in the beginning days of this Republic regarding the extent, scope, and reach of each of these two distinct jurisdictions remains unchanged and forms the foundation and basis for the smooth workings of state governmental systems in conjunction with the federal government (Becraft Jr. 2017). State jurisdiction remains largely what it was under the Articles of Confederation, when 'The confederated States possessed absolute, complete and full jurisdiction over property and persons located within their borders' (Becraft Jr. 2017).

\section{Federal Control of Interstate Commerce}

The exception laid out in the Alabama case regarding navigable waters stems from an enumerated power. The Commerce Clause provided the federal government with the authority "to regulate commerce with foreign nations, and among the several states, and with the Indian tribes" (US Const. art. I, $\S 8$, cl. 3). Following adoption, one of the first questions that faced the Court was whether control over interstate commerce allowed the national government to reach inside state borders. To the degree that state control of waterways and intrastate commerce might affect interstate commerce, state law could be preempted. But even preemption powers were limited by state sovereignty.

\section{Preemption}

Preemption doctrine finds its constitutional anchor in the Supremacy Clause:

This Constitution, and the Laws of the United States which shall be made in Pursuance thereof. . . shall be the supreme Law of the land; and the Judges, in every State shall be bound thereby, any Thing in the Constitution or Laws of any State to the Contrary notwithstanding. (US Const. art. VI, cl. 2)

By making the Constitution the supreme law of the land, federal legislation consistent with Congress's enumerated powers have primacy over state measures that conflict with them. In 1819, Chief Justice John Marshall explained, "States have no power, by taxation or otherwise, to retard, impede, burden, or in any manner control, the operations of the constitutional laws enacted by Congress to carry into execution the powers vested in the general government" (McCulloch v. Maryland 1819, p. 436). In the years that have elapsed since McCullough v. Maryland, the Court has repeatedly underscored "that state law that conflicts with [constitutional] federal law is 'without effect'” (Cipollone v. Liggett Grp., Inc. 1992, p. 516 (internal citation omitted)).

As a matter of law, there are two kinds of preemption: express and implied. Both are relevant to understanding the constitutional limits of federal power vis-à-vis UAS. 
Express preemption occurs where a federal statute explicitly confirms Congress's intention to preempt state law. As the Court noted in 1842 in response to an effort by states to override the Fugitive Slave Act,

[I]f Congress have a constitutional power to regulate a particular subject, and they do actually regulate it in a given manner, and in a certain form, it cannot be, that the state legislatures have a right to interfere, and as it were, by way of complement to the legislation of Congress, to prescribe additional regulations, and what they may deem auxiliary provisions for the same purpose. In such a case, the legislation of Congress, in what it does prescribe, manifestly indicates, that it does not intend that there shall be any further legislation to act upon the subject-matter. (Prigg v. Pennsylvania 1842, pp. 618-619)

In such cases, "no state is at liberty ... to interfere with the operation of a law of Congress" (N.Y. Cent R.R. Co. v. Winfield 1917, p. 153).

Congress' intent also may be "implicitly contained in its structure and purpose." (Jones v. Rath Packing Co. 1977, p. 525). In the case of implied preemption, the issue may be one of either conflict preemption or field preemption.

In the former (conflict preemption), state law directly conflicts with federal law. The dilemma arises from the impossibility of complying with both state and federal regulations or where the state law creates an obstacle to Congressional intent in enacting the measure in the first place. There is thus an actual barrier to achieving the full purpose of the federal measure.

A good example stems from a case that arose in the early nineteenth century, in response to a New York state law that gave Robert Livingston and Robert Fulton the exclusive right to operate steamboats on waters within the state. The legislation brought state measures into conflict with an act of Congress that regulated coastal trade. In Gibbons v. Ogden, Chief Justice Marshall famously explained that the power to regulate interstate commerce, "can never be exercised by the people themselves, but must be placed in the hands of agents, or lie dormant" (Gibbons v. Ogden 1824, p. 189). Marshall continued, "We know of no rule for construing the extent of such powers other than is given by the language of the instrument which confers them, taken in connexion [sic] with the purposes for which they were conferred" (Gibbons v. Ogden 1824, p. 189).

Justice William Johnson, in his concurrence, agreed that "while the power over the subject is yielded to the States, for obvious reasons, an absolute control is given over State legislation on the subject, as far as that legislation may be exercised, so as to affect the commerce of the country" (Gibbons v. Ogden 1824, p. 236). The Constitution is "altogether in favour of the exclusive grants to Congress of power over commerce" (Gibbons v. Ogden 1824, p. 236). What this meant in the context of Gibbons was that a dormant federal power existed, preventing the states from legislating in this realm - in this case, passing legislation discriminating against, or excessively burdening, interstate commerce.

In the case of field preemption, Courts assume that Congress means to prohibit states from acting in an area, where the regulatory scheme is so pervasive as to "occupy the field." In 1947, Justice Frankfurter explained that where states and the federal government have converging yet separate interests, collaboration should be assumed, "unless Congress has left no doubt that it was so bent on avoidance of 
all possible conflict that it left no room for concert" (Rice v. Santa Fe Elevator Corp. 1947, p. 242). Chief Justice Warren, on behalf of the Court, later picked up on this language in support of federal supersession (Pennsylvania v. Nelson 1956, p. 502). Examining the notorious Smith Act (which outlawed advocating overthrowing any federal, state or local government by force and violence), as well as the Communist Control Act of 1954 (which declared "that the Communist Party of the United States, although purportedly a political party, is in fact an instrumentality of a conspiracy to overthrow the Government of the United States," and provided penalties for membership of the Communist Party), the Court concluded, "Taken as a whole, [the statutory measures] evince a congressional plan which makes it reasonable to determine that no room has been left to the States to supplement it" (Pennsylvania v. Nelson 1956, pp. 503-504). Resultantly, "a state sedition statute is superseded regardless of whether it purports to supplement the federal law" (Pennsylvania v. Nelson 1956, p. 504). Having treated sedition "as a matter of vital national concern," it ceased being "a local enforcement problem" (Pennsylvania v. Nelson 1956, p. 505). It fell to Congress, not the states, "to provide for the common defense, to preserve the sovereignty of the United States as an independent nation, and to guarantee to each State a republican form of government" (Pennsylvania v. Nelson 1956, p. 505 (quoting 50 U.S.C. §781(15)) (repealed 1993)).

\section{Navigable Waterways}

Waterways presented one of the earliest challenges to how to understand where, and under what circumstances, federal dominion over interstate commerce preempted state measures directed toward intrastate commerce - a question that now presents in the context of UAS.

The first, most notable case on waterways was Gibbons v. Ogden. The Court considered navigation of waterways to be central to federal control over interstate commerce. Chief Justice Marshall explained, "Commerce, undoubtedly, is traffic, but it is something more: it is intercourse. It describes the commercial intercourse between nations, and parts of nations, in all its branches, and is regulated by prescribing rules for carrying on that intercourse" (Gibbons v. Ogden 1824, pp. 189-190). The key to understanding the Constitutional text of Article I, § 8, cl. 3 lay in the word "among." That clause excluded the interior traffic of a state. To have enumerated the power presupposed that something else was not enumerated (expressio unius, exclusio alterius) - namely, "the exclusively internal commerce of a state" (Gibbons v. Ogden 1824, p. 195). Marshall explained:

The genius and character of the whole government seem to be, that its action is to be applied to all the external concerns of the nation, and to those internal concerns which affect the States generally; but not to those which are completely within a particular State, which do not affect other States, and with which it is not necessary to interfere, for the purpose of executing some of the general powers of the government. The completely internal commerce of a State, then may be considered as reserved for the State itself. (Gibbons v. Ogden 1824, p. 195)

Federal power did not extend over matters purely internal to a state. 
Nor did federal power extend to inspection laws, which "form a portion of that immense mass of legislation which embraces everything within the territory of a State, not surrendered to the general government: all which can be most advantageously exercised by the States themselves" (Gibbons v. Ogden 1824, p. 203). Marshall wrote, "Inspection laws, quarantine laws, health laws of every description, as well as laws for regulating the internal commerce of a State, and those which respect turnpike roads, ferries, \&c., are component parts of this mass. No direct general power over these objects is granted to Congress; and, consequently, they remain subject to State legislation (Gibbons v. Ogden 1824, p. 203 (emphasis added)). Marshall recognized the limits on the national government that the Founding generation had built into the structure of the Constitution: theirs was a government of "only certain enumerated powers," while state governments "retain and exercise all powers not delegated to the Union" (Gibbons v. Ogden 1824, p. 205). But where states acted outside their authority and came into conflict with federal powers, state measures would be preempted.

As much as the federal government might have control over navigable waterways in relation to interstate commerce, there were hard limits. The common law system of riparian water rights had long recognized that landowners with property abutting a navigable waterway held a right to make reasonable use of the waterway as it crossed their land. Such rights include the right to access the water for hunting and fishing, for transportation, for building structures, or for leisure. If the waterway was not navigable, individuals could obtain exclusive right to use the water. Otherwise, they were limited to "reasonable" use, or use in proportion to their frontage along the water. Like air, water was a public good.

At the formation of the country, the authority for riparian and public rights transferred to states - not the federal government. State laws vary on the specifics, but as a general matter, the limit of title for a riparian owner of lands on tidal waters is the low-water mark, while the title to the lands below the low-water mark line is held by the state (see, e.g., United States v. Pa. Salt Mfg. Co. 1926, p. 479; Appeal of York Haven Water \& Power Co. 1905, p. 97; Wainwright v. McCullough 1869, p. 66; Commonwealth ex rel. Hensel v. Young Men's Christian Ass'n of Warren 1895, p. 121; Black v. Am. Int'l Corp. 1919, p. 738).

In other words, states own the beds under navigable waters, extending to the low-water mark on both sides of the waterway, while the landowner's rights apply between the low- and high-water marks, which is where state police powers hold sway. As one state supreme court explained, "The lands of an abutting property owner below [the] high-water mark are subject to the exercise of the police power of the state as the protector of highways and to the control of the United States as the guardian of the rights of navigation over navigable waters" (United States v. Pa. Salt Mfg. Co. 1926, p. 480).

The state's power over the lands of a landowner and over its own lands can be distinguished.

The exercise of this power over lands below high-water mark is closely analogous to that over lands within the limits of a land highway.... The sole right any one (other than the landowner) has in the lands below high-water mark and above low water is the right of 
navigation. The state may curtail this right, or take it away in toto. The landowner cannot of right obstruct navigation over his lands any more than he can of his own right encroach upon a highway on his lands. The state, however, may give him permission to build a construction which is an obstruction. (United States v. Pa. Salt Mfg. Co. 1926, p. 480)

Construction above the low-water mark belongs to the landowner. But where it extends below the low-water mark, while it is still his property, it is not his landed property. Instead, it is his property bedded in the lands of the state, because the state agreed to its construction (United States v. Pa. Salt Mfg. Co. 1926, pp. 480 481). Congress has recognized states' title to submerged navigable lands (the beds underneath navigable waterways) in the Submerged Lands Act of 1953 (43 U.S.C. $\S 1301-1315)$.

Waterways are far from the only area where federal and state sovereignty come into conflict. Railroads, like waterways, peregrinate between states. They play a central role in interstate commerce, even as they impact matters entirely internal to a state. For railroads, the Supreme Court has repeatedly found that federal law preempts state actions (see, e.g., Balt. \& Ohio R.R. Co. v. Interstate Commerce Comm'n 1911 (finding Congressional labor regulations constitutional, despite their applicability to railway employees solely engaged in intrastate commerce) and Southern Ry. Co. v. United States 1911 (holding that Congress may make safety regulations for vehicles moving entirely in intrastate traffic if there is a real or substantial connection to the safety of interstate commerce)).

In the early twentieth century, a series of cases further bolstered federal power. At that time, the Houston East \& West Texas Railway Company, Houston and Shreveport Railroad Company, and the Texas and Pacific Railway Company all operated rail lines between Texas and Shreveport, Louisiana. When the Texas Railroad Commission required that the railroads charge more for freight leaving Texas than transported within state bounds, the Interstate Commerce Commission (ICC) objected. The railroads subsequently challenged an ICC order setting maximum rates for shipping, arguing that the ICC lacked authority over intrastate trade (Houston, E. \& W. Tex. Ry. Co. v. United States 1914, p. 345).

Writing for the majority, Justice Charles Evans Hughes explained that Congress, which had delegated its authority to the ICC, had authority over interstate carriers as instruments of interstate commerce. Congress's power under Article I, $\S 8$, cl. 3 :

necessarily embraces the right to control their operations in all matters having such a close and substantial relation to interstate traffic that the control is essential or appropriate to the security of that traffic, to the efficiency of the interstate service, and to the maintenance of conditions under which interstate commerce may be conducted upon fair terms and without molestation or hindrance. (Houston, E. \& W. Tex. Ry. Co. v. United States 1914, p. 351)

The fact that the carriers conducted intrastate and interstate commerce was of little moment. Congress's "complete and paramount authority" over the latter preempted any effort by the state to interfere (Houston, E. \& W. Tex. Ry. Co. v. United States 1914, p. 351). Because discrimination in pricing adversely impacted interstate commerce, it was immaterial whether the discrimination came from interstate rates or wholly intrastate rates (Houston, E. \& W. Tex. Ry. Co. v. United States 1914, pp. 353-354). 


\section{Navigable Airspace}

When aircraft first appeared in the early twentieth century, there were no federal or state measures regulating their use. Insofar as airplanes were manufactured and flown within a state's borders, by citizens of the state, they were matters of local interest. But as their use expanded and the technology bolstered by their role in World War I advanced, safety concerns quickly became paramount. Simultaneously, the new industry offered untold opportunities for economic growth. Much like drone manufacturers in Nevada today, the aviation industry urged national leaders to introduce regulations that would ensure safety and thus lower public apprehension about the use of aircraft.

In 1922, the Senate considered the first bill to govern civil air navigation (H. Rep. No. 69-572 1926, p. 7). It took until 1926, however, for legislation to be passed. According to the House of Representatives' report, "It should be clearly borne in mind that the purpose of the [legislation] is strictly the promotion of commercial aviation" (H. Rep. No. 69-572 1926, p. 8). The driving force behind the law was to find a way to support the nascent aircraft industry.

Accordingly, the law gave the Secretary of Commerce wide discretion to ensure "that individual operators or other agencies should not be unduly hampered by restrictions or regulations until experience might prove them necessary" (H. Rep. No. 69-572 1926, p. 8). It charged the Secretary of Commerce with finding ways to capitalize on the new technology, issuing and enforcing rules for flight, providing a licensing regime for "airmen" (pilots), certifying aircraft, and establishing airways (Air Commerce Act of 1926, §§ 2-3). The Act was careful to distinguish between interstate or foreign air commerce and the internal affairs of the states, acting only in relation to the former.

The legislation created a new Assistant Secretary of Commerce to focus on "fostering air commerce," while the Department of Commerce created a new Aeronautics Branch (Air Commerce Act of 1926, § 7). It authorized the Secretary of Commerce "to designate and establish civil airways and ... to establish, operate, and maintain along such airways all necessary air navigation facilities except airports" (Air Commerce Act of 1926, § 5(b)). Reflecting the sovereignty of state control over land and buildings within their purview, the airports themselves were to be owned and operated locally, either by government entities or independent actors.

The statute defined "navigable airspace" as "airspace above the minimum safe altitudes of flight prescribed by the Secretary of Commerce," which would be "subject to a public right of freedom of interstate and foreign air navigation" (Air Commerce Act of 1926, $\S 10$ ). Thus, like the shores of navigable rivers and the soil beneath them, the land itself and the air immediately above the land fell within state domain. It was only in relation to aircraft traveling in navigable airspace, and thus liable to movement between states, where federal power held any sway.

The comparisons to marine navigation laws were hard to ignore: like water flowing between states, movement in the air had implications for interstate commerce. The House of Representatives explained, "air space, with its absence of fixed roads and tracks and aircraft with their ease of maneuver, present as to transportation 
practical and legal problems similar to those presented by transportation by vessels upon the high seas" (H. Rep. No. 69-572 1926, p. 9).

Accordingly, Congress looked to marine navigation laws for guidance. The safety inspection features, for instance, adopted for aircraft, were nearly identical to those applied to vessel registration and inspection laws that had been introduced in 1789 and 1838 (H. Rep. No. 69-572 1926, p. 10). The requirements had been applied to all craft upon navigable waters, "whether the craft are engaged in interstate or intrastate transportation, or are engaged in commercial or noncommercial operations" $(\mathrm{H}$. Rep. No. 69-572 1926, p. 10). In similar fashion, the aids to navigation were consistent with those provided by the Bureau of Lighthouses and the Coast and Geodetic Survey of the Department of Commerce (H. Rep. No. 69-572 1926, p. 10).

The House of Representatives asserted, "The declaration of what constitutes navigable air space is an exercise of the same source of power, the interstate commerce clause, as that under which Congress has long declared in many acts what constitutes navigable or nonnavigable waters" (H. Rep. No. 69-572 1926, p. 10). Pari passu, "The public right of flight in the navigable air space owes its source to the same constitutional basis which, under decisions of the Supreme Court, has given rise to a public easement of navigation in the navigable waters of the United States, regardless of the ownership of the adjacent or subjacent soil" (H. Rep. No. 69-572 1926, p. 10). Congress took the laws regarding water transportation and applied them to the air: "The whole framework and, in many cases, the very language of the bill may fairly be said to be merely the application to air transportation of provisions of statutes and principles of law long established as to water transportation" (H. Rep. No. 69-572 1926, p. 10).

Reflecting the enumerated powers in Article I, $\S 8$, cl. 3, the legislation was as much external as internal. The House of Representatives noted that the declarations of the sovereignty of the United States as against foreign nations in the air space above the country reflected the International Air Navigation Convention (H. Rep. No. 69-572 1926, p. 10).

In 1938 Congress passed a new statute in which it asserted a new, Federal power:

The United States of America is hereby declared to possess and exercise complete and exclusive national sovereignty in the air space above the United States, including the air space above all inland waters and the air space above those portions of the adjacent marginal high seas, bays, and lakes, over which by international law or treaty or convention the United States exercises national jurisdiction. (Civil Aeronautics Act of 1938, § 1107(i)(3))

The Supreme Court later stated that this clause "originated in the Air Commerce Act of 1926" (Braniff Airways, Inc. v. Neb. State Bd. of Equalization \& Assessment 1954, p. 595) (The 1926 statutes had declared "that the Government of the United States has, to the exclusion of all foreign nations, complete sovereignty of the airspace over the lands and waters of the United States (Air Commerce Act of 1926, $\S 6)$ ).

The Court, nevertheless, offered an interpretation of the 1926 legislation that allowed for an embrace of state power: the 1926 Act "did not expressly exclude the sovereign powers of the states" (Braniff Airways, Inc. v. Neb. State Bd. of Equalization \& Assessment 1954, p. 595 (emphasis added); H. Rep. No. 69-572 
1926, p. 10). Thus, despite the overt claim in the 1938 statute to national sovereignty over US airspace vis-à-vis other countries, the Court did not see the 1938 statute as altering state sovereignty in any way.

In coming to its conclusion, the Court also looked to state assertions of their rights. After Congress had passed the Air Commerce Act of 1926, more than 20 states had adopted a Uniform Aeronautics Act, in which three separate provisions indicated "that the states did not consider their sovereignty affected by the National Act except to the extent that the states had ceded that sovereignty by constitutional grant" (Braniff Airways, Inc. v. Neb. State Bd. of Equalization \& Assessment 1954, p. 595). The language of these three provisions is noteworthy. The first clause reasserted state sovereignty over airspace: "Sovereignty in the space above the lands and waters of this State is declared to rest in the State, except where granted to and assumed by the United States pursuant to a constitutional grant from the people of this State" (Unif. Aeronautics Act \$2 1922). The second clause read, "The ownership of the space above the lands and waters of this State is declared to be vested in the several owners of the surface beneath, subject to the right of flight described in Section 4" (Unif. Aeronautics Act $\$ 3$ 1922). The third clause explained the lawfulness of flight:

\footnotetext{
Flight in aircraft over the lands and waters of this State is lawful, unless at such a low altitude as to interfere with the then existing use to which the land or water, or the space over the land or water, is put by the owner, or unless so conducted as to be imminently dangerous to persons or property lawfully on the land or water beneath. The landing of an aircraft on the lands or waters of another, without his consent, is unlawful, except in the case of a forced landing. For damages caused by a forced landing, however, the owner or lessee of the aircraft or the aeronaut shall be liable....." (Unif. Aeronautics Act $\$ 4$ 1922)
}

States, in other words, fully retained control over the airspace immediately over state land and waters. Although the recommendation for states to adopt the uniform code was withdrawn by the National Conference of Commissioners on Uniform State Laws in 1943, for those states where it had been adopted, it continued to be in effect (Braniff Airways, Inc. v. Neb. State Bd. of Equalization \& Assessment 1954, p. 595).

As in 1926, safety concerns drove enactment of the 1938 statute. In June 1935, Congress had directed the Committee on Commerce to investigate a series of airplane incidents and to make recommendations on how best to improve air safety (S. Res. 146 1935) (directing the committee to determine, "[W]hat legislation, if any, shall be adopted in the interest of safety of life and property transported in interstate air commerce, and what legislation, if any, shall be adopted to prevent accidents in the air and to provide appropriate safeguards for their prevention")). With 17,681 licensed civil pilots flying 7300 licensed civil airplanes between 2327 airports, a complex system had emerged (S. Rep. No. 75-1661 1938, p. 2). The impact on consumers was significant: more than 1,250,000 passengers per year, and over 1.25 billion pound-miles of mail per month were being transported (S. Rep. No. 75-1661 1938 , p. 2). Increased competition meant that efforts were being made to cut costs with dramatic implications for passenger safety (S. Rep. No. 75-1661 1938, p. 2). In a classic "race to the bottom," Congress felt the need to step in: "[T]his bill will 
not only promote an orderly development of our Nation's civil aeronautics, but by its immediate enactment prevent the spread of bad practices and of destructive and wasteful tactics resulting from the intense competition now existing within the aircarrier industry" (S. Rep. No. 75-1661 1938, p. 2). To do this, Congress applied "[t]he recognized and accepted principles of the regulation of public utilities" (S. Rep. No. 75-1661 1938, p. 2).

In 1946, the Court went on to recognize that despite the federal government's assertion of "exclusive national sovereignty" and the right of freedom in air transit, land owners could recover damages for use of navigable airspace over an individual's property (United States v. Causby 1946, p. 256). The Fifth Amendment to the Constitution protects against "private property be[ing] taken for public use, without just compensation" (US Const. amend. V).

In the 1946 case of United States v. Causby, a North Carolina citizen owned a chicken farm that was located near an airport routinely used by the US military. The Court determined that a servitude had been imposed upon the land. Although an ancient common law doctrine (cujus est solum ejus est usque ad coelum) recognized that ownership of land extends to the periphery of the universe, the Court found it inapposite to the modern world (United States v. Causby 1946, pp. 260-261).

The air above the minimum safe altitude of flight, as outlined by the Civil Aeronautics Authority, could be considered the public domain - much as a public highway. However, anything below that altitude, not in the navigable air space, did not constitute the public domain. Use of this space, if permanent and not merely temporary, "would be a definite exercise of complete dominion and control over the surface of the land" (United States v. Causby 1946, p. 262).

Navigable airspace was defined at the time as "airspace above the minimum safe altitudes of flight prescribed by the Civil Aviation Administration (49 U.S.C. $\S 180$ 1946). The Court wrote, "The fact that the planes never touched the surface" was irrelevant (United States v. Causby 1946, p. 262). Individual property rights prevailed: "The landowner owns at least as much of the space above the ground as he can occupy or use in connection with the land. The fact that he does not occupy it in a physical sense - by the erection of buildings and the like - is not material" (United States v. Causby 1946, p. 264 (internal citations omitted)). For the Court,

[t]he superadjacent airspace at [a] low altitude is so close to the land that continuous invasions of it affect the use of the surface of the land itself. We think that the landowner, as an incident to his ownership, has a claim to it and that invasions of it are in the same category as invasions of the surface. (United States v. Causby 1946, p. 265)

Sovereignty in airspace remained in the state, except where it had been granted to and assumed by the United States (United States v. Causby 1946, p. 266, citing N.C. Gen. Stat. § 63-11 1943). Thus, while the navigable airspace may be part of the public domain, the immediate reaches of the adjacent airspace belonged to the farmer.

Following Causby, Congress redefined "navigable airspace" to mean "airspace above the minimum altitudes of flight prescribed by regulations issued under this chapter," including "airspace needed to insure safety in take-off and landing of 
aircraft" (Federal Aviation Act of 1958, § 1; 49 U.S.C. § 1301(24); 49 U.S.C.A. § 1301(24)). In 1962, under this new definition, the Court considered whether takeoff and landing zones appropriated airspace. Writing for the Court, Justice Douglas held that the noise from the aircraft amounted to an air easement over the entire county, making use of the airspace a taking (Griggs v. Allegheny 1962, p. 85). The fact that Congress had defined "navigable airspace" differently had little effect on property rights. To the contrary, it suggested that any exercise of dominion over adjacent airspace would have to be compensated.

At the time of Griggs, the minimum safe altitude was $500 \mathrm{ft}$ or $1000 \mathrm{ft}$, "[e]xcept where necessary for takeoff or landing." Nevertheless, as the Court had stated in Causby,

[T] he use of land presupposes the use of some of the airspace above it. Otherwise, no home could be built, no tree planted, no fence constructed, no chimney erected. An invasion of the superadjacent airspace will often affect the use of the surface of the land itself. (Griggs v. Allegheny 1962, p. 89) (internal quotes and citations omitted)

The glide path, and the land underneath it, was as essential for the airport to operate as land would be for a dam to work (Griggs v. Allegheny 1962, p. 90). The fact that it was in the air was of no consequence. It was the property underneath that was affected.

\section{Unmanned Aerial Systems}

Much like the regulation of the waterways, or the piloted aircraft industry, to the extent that UASs in navigable airspace affect the safety of piloted aircraft, the federal government has a role to play. This has been Congress's, as well as the FAA's primary emphasis. In 2012, FMRA prohibited the FAA from regulating model aircraft less than $55 \mathrm{lb}$, unless they were flown within 5 miles of an airport, in which case certain criteria would have to be met (FAA Modernization and Reform Act of 2012, § 336(a)). The statute went on to require the FAA to figure out how to integrate all classes of UAS into the NAS (FAA Modernization and Reform Act of $2012, \S 336(\mathrm{c}))$.

To the extent that the law emphasizes integration into the NAS and safety concerns as narrowly construed (e.g., interference with piloted aircraft in the NAS), it is on firm footing. But to the extent that federal actions begin to interfere with property rights, or state sovereignty over their citizens and democratic institutions, then the federal government is on much shakier grounds.

Despite the statutory prohibition on regulating hobbyists, for instance, for reasons related to "safety," the FAA is now attempting to regulate all individuals flying sUAS. The agency, for instance, claims jurisdiction over any UAS used for agricultural purposes (an area historically within the state domain), for commercial use (even if located within a state for internal state business), or as a hobby (if outside VLOS). It has, moreover, gone on to issue regulations that require hobbyists to meet federal "guidelines" - even when flown in airspace immediately adjacent to 
property. What is remarkable about these provisions is that they apply, ostensibly, from the ground up - land and airspace constitutionally and historically within the state domain.

States, not the federal government, have control over persons and property within their bounds. This includes land. It includes people. It includes the beds of navigable waterways and adjacent airspace. And it includes UAS, outside of requirements placed on UAS that affect either the safety of aircraft in NAS, or, consistent with the test laid out in United States v. Lopez (discussed, infra), interstate commerce. Current state UAS provisions further demonstrate the extent to which UAS falls within state police powers.

\section{Adjacent Airspace: State Sovereignty Up to $500 \mathrm{Ft}$}

The FAA asserts that it controls all aircraft in the NAS, broadly understood. This claim rather begs the question of what, precisely, constitutes the NAS, what happens to UAS outside the NAS, and how this claim may interfere with control over land and air long considered as an aspect of state, and not federal, sovereignty. A strong constitutional argument can be brought to bear that below $500 \mathrm{ft}$, it is the states, and not the federal government, that have the authority to regulate UAS.

The FAA divides airspace into five classes: above 60,000 ft is Class E, between 18,000 and 60,000 ft is Class A, between 1200 and 18,000 ft is Class E, and in the presence of an airport Classes B, C, and D. Class G is from the ground, up to $1200 \mathrm{ft}$ above ground level - including mountains over 10,000 ft high. FAAcontrolled airspace is the realm within which manned aircraft operate. This area has been defined by where it is safe to fly aircraft.

Navigable airspace does not extend down to the ground - nor could it, without violating state sovereignty. Under the Code of Federal Regulations, low-flying aircraft are prohibited (14 C.F.R. $§ 91.119$ 2016). Over any congested area of a city, town, or settlement, or an open air assembly of persons, pilots must maintain an altitude of $1900 \mathrm{ft}$ above the highest obstacle within a horizontal radius of $2000 \mathrm{ft}$ of the aircraft (14 C.F.R. $§ 91.119$ (b) 2016). Over non-congested areas, pilots must stay above $500 \mathrm{ft}$ from the surface, and not closer than $500 \mathrm{ft}$ from "any person, vessel, vehicle, or structure" (14 C.F.R. § 91.119(c) 2016). Although helicopters can go lower than fixed-wing aircraft, they are limited to routes or altitudes specifically prescribed by the FAA, which has had to adapt its provisions to take account of the increasing use of helicopters for emergency medical services (14 C.F.R. § 91.119(d) 2016; 14 C.F.R. $§ 91,2016$ (laying out the extensive restrictions on helicopters)).

Below 500 feet, state sovereignty protects the airspace and land below it. Numerous states have already asserted their constitutional power through provisions that make use of UAS in adjacent airspace, without the consent of the landowner, a trespass (see, e.g., Cal. Civ. Code $\S 853$ 2017; La. Stat. Ann. § 14:63, 2016; Nev. Rev. Stat. Ann. § 493.103(1) 2015; N.C. Gen. Stat. Ann. § 15A-300.1(b) 2016); Or. Rev. Stat. Ann. § 837.380(1) 2016; Tenn. Code Ann. §§ 39-13-903(a)(1), (3) 2016). In California, as explained above, the UAS does not even need to enter onto the land for the tort to occur (Cal. Civ. Code $\S 1708.8$ (a) 2017). The state adapted its laws related to constructive invasion of privacy to drones (Cal. Civ. Code $\S 1708.8$ 
2017; 2015 Cal. Legis. Serv. 4388 n.d). The previous statute, which was amended to take account of UAS, was directed at protecting individuals from paparazzi. It made it illegal to attempt "to capture, in a manner that is offensive to a reasonable person, any type of visual image, sound recording, or other physical impression of the plaintiff engaging in a private, personal, or familial activity, through the use of any device, regardless of whether there is a physical trespass, if this image, sound recording, or other physical impression could not have been achieved without a trespass unless the device was used" (Cal. Civ. Code $\$ 1708.8$ (b) 2015).

Some states, such as California and Louisiana, do not put any ceiling on the air above private property (see, e.g., Cal. Civ. Code $\$ 1708.8$ (b) 2015; La. Stat. Ann. $\S 14: 63$ 2016). Any entry is considered a trespass. Where ceilings have been set, they vary from $250 \mathrm{ft}$ above the ground (Nevada) to up to $500 \mathrm{ft}$ above property (Tennessee) - a number reflecting the navigable airspace, as set by the Code of Federal Regulations (Tennessee code directly ties its definition of criminal trespass to include when an UAS enters the portion of airspace above an owner's land not regulated as navigable airspace by the FAA) (Tenn. Code Ann. § 39-14-405 2016). In Nevada, the state legislature has similarly prohibited flying a drone within $500 \mathrm{ft}$ of any critical infrastructure (Nev. Rev. Stat. Ann. § 493.109 2015). The trouble with sUAS is that they are typically flown at a level lower than navigable airspace. Efforts by the FAA to intrude into this sphere run directly into conflict with state sovereignty.

Causby tied ownership and the right to exclude individuals from private property to nuisance and the harm that might follow from someone flying over land. It thus recognized a nuisance-based trespass in the airspace. What is notable about current state UAS law is that they are applying ordinary trespass laws to address UAS incursions into private airspace. It is thus not just the noise that may be a factor, but merely the entry into the space, which changes the landowner's ability to use the air above the property. FAA measures that attempt to regulate sUAS on private property, outside the NAS, and not in the path of aircraft landing or taking off reach too far into the state realm to pass constitutional muster.

\section{Noneconomic Activities}

What about some of the other criminal UAS provisions being passed by the states? Could the federal government act in these areas? For instance, what if the federal government wanted to pass a measure prohibiting all UAS from carrying weapons? Right now, it is the states, and not the federal government, that are regulating this realm. They have issued a range of measures, discussed above, affecting the right of LEAs and private citizens to weaponized drones. Setting the Second Amendment concerns to the side, with police powers central to state sovereignty, it could be argued that federal efforts to interfere in this area cross constitutional boundaries. Weaponization is precisely the kind of noneconomic activity at issue in the 1995 case of United States v. Lopez, in which the Supreme Court trimmed back federal Commerce Clause powers.

In 1995, the Court established the outer limits of the Commerce Clause, as it considered an effort by Congress to pass the Gun-Free School Zones Act of 
1990 (Gun-Free School Zones Act, §1702). Alfonzo Lopez, a senior in high school, had brought a concealed gun into his San Antonio, Texas, high school in violation of the statute (United States v. Lopez 1995, p. 549). In holding against the federal government, Chief Justice Rehnquist went back to the Founding ideals: "We start with first principles. The Constitution creates a Federal Government of enumerated powers" (United States v. Lopez 1995, p. 552). Quoting Madison in The Federalist No. 45, he noted that the reason that the powers of state governments were "numerous and indefinite," in contrast to the restrictions placed on the federal government, was to ensure the protection of individual liberty (United States v. Lopez 1995, p. 552, quoting Gregory v. Ashcroft 1991, p. 458). Rehnquist looked to the Court in the 1991 case of Gregory v. Ashcroft: "Just as the separation and independence of the coordinate branches of the Federal Government serve to prevent the accumulation of excessive power in any one branch, a healthy balance of power between the States and the Federal Government will reduce the risk of tyranny and abuse from either front" (United States v. Lopez 1995, p. 552).

Rehnquist laid out the test for what would be considered within the remit of the Commerce Clause. Congress could regulate activity that fell into one of three categories: channels of interstate commerce, instrumentalities of interstate commerce (or persons/things in interstate commerce), and activities having a substantial relation to interstate commerce (United States v. Lopez 1995, p. 552). Merely carrying a gun near a school was insufficient for a Commerce Clause hook. It was neither a channel of interstate commerce nor something mid-transport. Nor did carrying a gun have a substantial relation to commerce, although school violence affected commerce. The mere act of carrying a gun was not enough to implicate the economic interests encapsulated in Article I, § 8(3).

Justice Thomas's concurrence in Lopez underscored the narrowness with which Article I $\S 8(3)$ had been understood at the Founding. "At the time the original Constitution was ratified," he wrote, "“commerce' consisted of selling, buying, and bartering, as well as transporting for these purposes" (United States v. Lopez 1995, p. 585). Citing The Federalist No. 4 (written by John Jay), No. 7 (written by Alexander Hamilton), and No. 40 (written by James Madison), Thomas recognized the consistent views held by these writers. Thomas noted that the view was not unique to federalists. He cited Letters of a Federal Farmer, a series of articles published by an anti-federalist between November 1787 and January 1788 in the Poughkeepsie Country Journal. These disparate political views, bolstered by the assumedly neutral Johnson's Dictionary, all agreed on a narrow understanding of commerce (United States v. Lopez 1995, p. 585). Based on this reading, Justice Thomas rejected the third part of Rehnquist's test. If activities that "substantially affect commerce" had been included in the meaning of Article I $\S 8(3)$, then why had Congress progressed to detail bankruptcy laws, the coining of money, and standard of weights and measures and the other enumerated powers listed in Articles I $\S$ 8(4)-(10)? He argued:

Put simply, much if not all of Art. I, $\S 8$ (including portions of the Commerce Clause itself), would be surplusage if Congress had been given authority over matters that substantially affect interstate commerce. An interpretation of cl. 3 that makes the rest of $\S 8$ superfluous 
simply cannot be correct. Yet this Court's Commerce Clause jurisprudence has endorsed just such an interpretation: The power we have accorded Congress has swallowed Art. I, §

8. (United States v. Lopez 1995, p. 589)

Justice Breyer disagreed. For him, the power to regulate commerce included the power to regulate even local activities, insofar as they significantly affected interstate commerce. Here, the cumulative effect was relevant. In his dissent, Breyer argued that the Court "must give Congress a degree of leeway in determining the existence of a significant factual connection between the regulated activity and interstate commerce" (United States v. Lopez 1995, p. 616). Breyer's view, however, did not carry the day. The impact of gun violence on the economy was not enough to give the federal government power over individuals carrying weapons. Efforts by federal government to regulate operating a weaponized drone would fall within the noneconomic activity reservation.

\section{Economic Activity}

Setting private and public use of UAS to one side for the moment, the FAA has gone further, attempting to regulate all commercial drones, even those flown within in the airspace adjacent to the ground. Here, federal Commerce Clause authorities come into direct conflict with state sovereignty over private property. To determine constitutionality, context matters.

\section{UAS Use in Agriculture}

Let us first consider a small organic farmer, selling at a local farmer's market. Can the federal government legally regulate the farmer's use of UAS to survey crops? The FAA's current claim that it has the right to do so raises constitutional problems.

Federal power over how businesses are run has expanded over time. In 1935, the Court struck down federal efforts to fix hours and wages because such measures were only indirectly related to commerce (A.L.A. Schechter Poultry Corp. v. United States 1935, p. 495). The case established a distinction between direct and indirect impact of intrastate transactions. If the activity to be regulated had a direct impact, it lay within Article I(8)(3). If indirect, it was outside Congressional control. Just 2 years later, however, the Court moved away from the formal distinction, adopting instead a formula, wherein intrastate activities with such a "close and substantial relation to interstate commerce" that control over them was "essential or appropriate" to protect such commerce from burdens and obstructions could be regulated (N.L.R.B. v. Jones \& Laughlin Steel Corp. 1937, p. 1). In 1941, the Supreme Court determined that the Commerce Clause was "not confined to the regulation of commerce among the states" (United States v. Darby 1941, p. 118). Instead, it extended to intrastate activities "which so affect interstate commerce or the exercise of the power of Congress over it as to make regulation of them appropriate means to the attainment of a legitimate end" (United States v. Darby 1941, p. 118).

Based on this logic, any wheat grown by a farmer, even if it was for personal consumption and not to be sold on the market, fell within Federal power (Wickard 
v. Filburn 1942, p. 111). In Wickard v. Filburn, a small farmer in Ohio had a wheat acreage allotment under a Department of Agriculture Directive of 11.1 acres. When he harvested just under 12 acres, saying that the extra wheat was for his own use, the Court unanimously upheld the federal penalty that had been applied. In doing so, the court explicitly rejected the Schechter Poultry direct versus indirect test. Even if the portion of wheat grown for home use was trivial, the amount was insufficient to "remove him from the scope of federal regulation where, as here, his contribution, taken together with that of many others similarly situated, is far from trivial" (Wickard v. Filburn 1942, pp. 127-128). Justice Jackson, writing for the Court, explained that even if an activity is local and not regarded as commerce, "it may still, whatever its nature, be reached by Congress if it exerts a substantial economic effect on interstate commerce, and this irrespective of whether such effect is what might at some earlier time have been defined as 'direct' or 'indirect'" (Wickard v. Filburn 1942, p. 125).

Using UAS to aid in agriculture, however, is different than growing the crops. Thus, while Congress may prohibit the local cultivation of certain plants (Gonzales v. Raich 2005, p. 1), it is limited in what it may constitutionally require of farms themselves.

Similarly, the federal government has introduced various measures to protect the safety of farmworkers (see, e.g., Fair Labor Standards Act, § 201 2015; Occupational Safety and Health Act 2015; the Federal Insecticide, Fungicide, and Rodenticide Act, $\S 136$ 2015). But states, not the federal government, govern almost all motor vehicle laws and regulations impacting farmers. See, e.g., State of N.J., Dep't of Agric. 2017. Many aspects of farming and farm equipment do not fall under federal regulations, when the activity is carried out on the farmland, or when products are being transported short distances. The US Department of Transportation, Federal Motor Carrier Safety Administration, is trying to expand its authority in this realm, but it is running up against strong state resistance. See, e.g., Seachrist 2011. The reason why is fairly clear: state police powers include broad authority to regulate roads and vehicles traveling over them, despite the almost inevitable impact of such provisions on interstate commerce. These powers extend to the regulation of adjacent airspace, and people, vehicles, and UAS traveling within it, where both private and commercial uses intermingle. States have a strong interest in protecting the safety and welfare of those within their bounds - one that, despite the FAA's claim to the contrary, involves control of adjacent airspace.

\section{UAS Use for Delivery of Goods}

What about the commercial use of UAS to deliver goods? This has attracted tremendous attention from Congress and the public, both because of the potential economic impact in greatly facilitating delivery services, as well as the convenience of such delivery. But federal power here is also limited. Unlike railroads, which run on tracks on land purchased by companies, the FAA is now contemplating regulation of commercial drones that may fly above private property or public roads. Yet both of these are firmly in the state domain. 
In 1959 the Supreme Court articulated state police powers in broad terms that acknowledged the importance of state sovereignty, even in the face of Commerce Clause claims:

The power of the State to regulate the use of its highways is broad and pervasive. We have recognized the peculiarly local nature of this subject of safety, and have upheld state statutes applicable alike to interstate and intrastate commerce, despite the fact that they may have an impact on interstate commerce. (Bibb v. Navajo Freight Lines, Inc., 1959, p. 523 1959)

The Court had long recognized state power over public highways.

In 1938, the Supreme Court considered a South Carolina statute that prohibited semitrailer motor trucks more than 90 in. wide, weighing more than 20,000 lb, from using highways (South Carolina State Highway Dept. v. Barnwell Bros. 1938, p. 180). The trial court had decided that the statute unreasonably burdened interstate commerce (South Carolina State Highway Dept. v. Barnwell Bros. 1938, p. 182). The Supreme Court observed, "South Carolina has built its highways and owns and maintains them" (South Carolina State Highway Dept. v. Barnwell Bros. 1938, p. 184). It continued, "[w]hile the constitutional grant to Congress of power to regulate interstate commerce has been held to operate of its own force to curtail state power in some measure, it did not forestall all state action affecting interstate commerce" (South Carolina State Highway Dept. v. Barnwell Bros. 1938, pp. at 184-185). Since 1829 ,

[I]t has been recognized that there are matters of local concern, the regulation of which unavoidably involves some regulation of interstate commerce but which, because of their local character and their number and diversity, may never be fully dealt with by Congress. Notwithstanding the commerce clause, such regulation in the absence of congressional action has for the most part been left to the states by the decisions of this Court. (South Carolina State Highway Dept. v. Barnwell Bros. 1938, p. 185)

While Article I(8)(3) might prohibit discrimination against interstate commerce, in the case of regulating the size and weight of trucks, there was nothing to indicate that the states would have to "curtail[] their power to take measures to insure the safety and conservation of their highways which may be applied to like traffic moving intrastate" (South Carolina State Highway Dept. v. Barnwell Bros. 1938, p. 187).

The Court emphasized the importance of the subject to state interests, "[f]ew subjects of state regulation are so peculiarly of local concern as is the use of state highways" (South Carolina State Highway Dept. v. Barnwell Bros. 1938, p. 187). States play the primary role in building them. They own them. They maintain them. "The state," moreover, "has a primary and immediate concern in their safe and economical administration" (South Carolina State Highway Dept. v. Barnwell Bros. 1938, p. 187). Virtually any regulation of the roads could affect interstate commerce - but this did not, in any way, diminish the strong state interest in regulating its own highways. Where Congress had not acted, the decision of what measures to introduce to regulate the highways lay firmly in the state domain. If Congress wanted to act in these areas, it was for Congress (and not the Courts) to do so. For the Court, South Carolina was well within its constitutional power to act (South Carolina State Highway Dept. v. Barnwell Bros. 1938, p. 196). 
The Court came to the same conclusion about a Pennsylvania statute that prohibited any cars carrying other vehicles over the head of the vehicle operator (Maurer v. Hamilton 1940, p. 598). In 1935, Congress had adopted the Motor Carrier Act, with the purpose of advancing motor carrier transportation for economic advantage (Motor Carrier Act 1935; George 1936). The following year, the Interstate Commerce Commission promulgated regulations to govern the "safety of operation and equipment" of cars in interstate commerce (George 1936, p. 254). Neither the law nor the regulations specifically addressed the safety hazards of cars carried over the cab.

The Court in 1940 recognized that the states had a central role to play: highways "are state owned, and, in general, are open in each state to use by privately owned and controlled motor vehicles of widely different character (Maurer v. Hamilton 1940, pp. 604-605). States, sensitive to local needs and conditions, long had been in charge of the safety of their roads (Maurer v. Hamilton 1940, p. 605). The effort by the federal government to assert national control raised "problems of peculiar difficulty and delicacy" (Maurer v. Hamilton 1940, p. 605). The state had merely been ensuring the safety of its own roads. Resultantly, "we can not regard the regulation as other than an exercise of the state's power to protect the safe and convenient use of its highways through the control of size and weight of motor vehicles passing over them" (Maurer v. Hamilton 1940, p. 598).

Texas also introduced a Motor Vehicle Act that limited the size of vehicles on its roads (Regulation of Vehicles on Rural Highways 1931, p. 507). The Supreme Court observed, "In exercising its authority over its highways the state is not limited to the raising of revenue for maintenance and reconstruction, or to regulations as to the manner in which vehicles shall be operated, but the state may also prevent the wear and hazards due to excessive size of vehicles and weight of load" (Sproles v. Binford 1932, p. 388). The objection, moreover, that state regulation of vehicles was repugnant to the Commerce Clause was "without merit” (Sproles v. Binford 1932, p. 389).

An examination of the acts of Congress discloses no provision, express or implied, by which there is withheld from the state its ordinary police power to conserve the highways in the interest of the public and to prescribe such reasonable regulations for their use as may be wise to prevent injury and damage to them. (Sproles v. Binford 1932, pp. 389-390, quoting Morris v. Duby 1927, p. 143)

In part because of "the special requirements of local conditions, the states" were free to act until Congress saw fit to determine otherwise (Sproles v. Binford 1932, p. 390). For the Supreme Court, the regulation of state highways was "akin to quarantine measures, game laws, and like local regulations of rivers, harbors, piers, and docks, with respect to which the state has exceptional scope for the exercise of its regulatory power, and which, Congress not acting, have been sustained even though they materially interfere with interstate commerce" (S. Pac. Co. v. Arizona ex rel. Sullivan 1945, p. 783).

For cases coming to the Court, state control over use of land within its bounds is presumed to be constitutionally valid - even if it interferes with interstate commerce, unless there is an excessive burden placed on it (Bibb v. Navajo Freight Lines, Inc., 
1959, p. 520). Should federal power be understood as extended to all airspace above private land and public roads, it would so eviscerate state police powers as to render them virtually nonexistent.

\section{Regulation of UAS Along Special Corridors}

What if the FAA wanted to set up special corridors to facilitate UAS for commercial purposes? Here, too, their ability to do so would be limited.

Zoning ordinances are regularly sustained under the police powers of the state (Village of Euclid v. Ambler Realty Co. 1926, p. 395) (recognizing that zoning ordinances can only be declared unconstitutional where they are "clearly arbitrary and unreasonable, having no substantial relation to the public health, safety, morals, or general welfare”). In 1989, for instance, a local land owner brought an action against a town and a number of its officials, challenging the constitutionality of a zoning ordinance (Greene v. Town of Blooming Grove 1989, p. 1061). The Court recognized that municipal zoning ordinances are presumed to be valid "and will not be held unconstitutional" if their "wisdom" was "at least fairly debatable" and it bore "a rational relationship to a permissible state objective" (Greene v. Town of Blooming Grove 1989, p. 1063, citing City of Cleburne v. Cleburne Living Center 1985, p. 440).

The authority to establish building ordinances, which apply to structures that extend into the air above property, are also clearly within state police powers. So, too, are ordinances that regulate things that go up into the air, such as billboards (Thomas Cusack Co. v. Chicago 1917, p. 526). In considering the constitutionality of one such ordinance, the Supreme Court noted that while it had thus far refrained, "from any attempt to define with precision the limits of the police power... its disposition is to favor the validity of laws relating to matters completely within the territory of the state enacting them" (Thomas Cusack Co. v. Chicago, pp. 530-531 (emphasis added)).

In 2002, a similar effort to establish that federal law preempted state regulations dealing with aerial advertising failed. Skysign International, Inc., operated under an FAA certificate of waiver, which allowed it to fly civil aircraft over densely populated areas (Skysign Int'1, Inc., v. Honolulu 2002, p. 1113). The city and county of Honolulu, Hawaii, issued a municipal ordinance that prohibited signage, including any portable sign, to be displayed outside the premises on which the activity was to be conducted (Skysign Int'l, Inc., v. Honolulu 2002, p. 1113). Before introducing the ordinance, Honolulu twice sought the FAA's advice as to whether it would be preempted by federal law. Both times, the FAA indicated that any local attempt to apply such an ordinance to aircraft would be preempted (Skysign Int'l, Inc., v. Honolulu 2002, p. 1113). It turns out, the FAA was wrong.

On appeal, the Ninth Circuit noted that "advertising is an area traditionally subject to regulation under the states' police power." The Court therefore presumed that federal law did not displace Honolulu's regulatory authority over advertising, absent a clear statement of the federal intent to do so (Skysign Int'1, Inc., v. Honolulu 2002, p. 1115). Although a statute claimed exclusive sovereignty over the airspace of the United States, it had been understood by the Supreme Court in Braniff merely 
as "an assertion of exclusive national sovereignty that did not expressly exclude the sovereign powers of the states" (Skysign Int'l, Inc., v. Honolulu 2002, p. 1116) (internal quotes and citations omitted). In the case of aerial advertising, the states still held power (Skysign Int'l, Inc., v. Honolulu 2002, p. 1118).

\section{Concluding Remarks}

Over the past 4 years, the federal government has become increasingly interested in regulating UAS. Simultaneously, state provisions have proliferated. Before the FAA becomes too eager to move into this realm, it needs to carefully consider the serious constitutional barriers to what it can do. The Constitution and the judiciary have long recognized state sovereignty over persons and land within their bounds. Police powers, reserved to the states, are broadly understood, even as the Court tends to give states deference. It is the states, and not the federal government, that regulate public roads and navigable waterways, outside of a narrow area, which has been accorded to Congress consistent with the Commerce Clause. It is the states, and not the federal government, that maintain jurisdiction of adjacent airspace up to $500 \mathrm{ft}$ above the ground. And it is to the states that we must look for future regulation of UAS.

In recognition of the deeply fact-dependent nature of efforts to regulate commercial operators, the FAA has said that it will consider preemption on a caseby-case basis (Operation and Certification of Small Unmanned Aircraft Systems 2016). The FAA has (quite rightly) not yet taken any action against any state or municipality. There are signs that the FAA is concerned about its constitutional limits. In Part 107, the FAA states that "laws traditionally related to state and local police power-including land use, zoning, privacy, trespass, and law enforcement operations-generally are not subject to Federal regulation" (Operation and Certification of Small Unmanned Aircraft Systems 2016). For "flight altitude, flight paths; operational bans; or any regulation of the navigable airspace," the FAA is merely recommending consultation with the FAA (Operation and Certification of Small Unmanned Aircraft Systems 2016). As set by the US Constitution and by case law, these areas are in the domain of state and local government.

In Part 107, the FAA explicitly recognized the role of state and local government: "State law and other legal protections may already provide recourse for a person whose individual privacy, data privacy, private property rights, or intellectual property rights may be implicated by a remote pilot's civil or public use of a UAS." The FAA made note in multiple places of state and local laws related to trespassing. In 2016, the General Counsel of the FAA underscored this point (National League of Cities 2016, p. 9). His remarks, however, fell short of the constitutional authorities afforded to the states. It is not just time, place, and manner that lie within the state realm, but their full police power and their dominion over persons, land, and airspace, within their bounds.

Before concluding, it is important to note that beyond the constitutional concerns, outlined above, federal involvement in UAS threatens individual rights and 
risks preventing the states from performing their important role as incubators of innovation.

\section{Endangering Rights}

As the federal government attempts to expand its authority into regulating UAS, there is a serious risk that it will use its control over the NAS in ways that undermine individual rights. This is already coming to pass.

In November 2016, videos shot by Native American drone pilots documenting human rights abuses in North Dakota quickly brought national and international attention to heavy-handed government tactics (Koebler 2016). The videos showed the police using percussion grenades, water cannons, and freezing water, at night, to try to disband protestors (Dewey 2016c; NODAPL Protest 2016; Ruptly 2016).

UAS filmed police actions during a Native American ceremony, when the police aimed their guns at unarmed civilians and fired pepper spray (Dewey 2016a). Drones operated by Native Americans also showed that the workers were continuing to drill at night (Dewey 2016b). These drone flights and video images were instrumental in attracting attention to what was happening in North Dakota. See, e.g., Stelloh et al. 2016.

As the police moved in to arrest protesters, the FAA issued a Temporary Flight Restriction (TFR) over Standing Rock (Sachs 2016; Goglia 2016; McNabb 2016a). The FAA claimed that it was required to do so when requested by law enforcement (McNabb 2016a). But the net effect was that media was shut out, while law enforcement drones and federal aircraft could continue to fly (Sachs 2016; McNabb 2016b). The FAA ostensibly had an exception for media to apply for special permission, but when efforts were made to do so, they were simply told "no" (McNabb 2016b).

The Standing Rock ban was not the first time that the FAA had acted to prevent journalists from documenting aggressive police tactics. In August 2014, the FAA agreed to a police request for a TFR for 12 days following the shooting of 189-year old Michael Brown in Ferguson, Missouri (USA Today 2014). Although the police initially cited security concerns, a Freedom of Information Act request submitted by the Associated Press turned up records between the FAA and a Kansas City Manager, noting that the police normally request only a mile radius TFR "to keep media out" (USA Today 2014).

Setting the First Amendment concerns to the side, the failure of the FAA to prevent the media black-out zone and its function as an instrument of the state raise serious concerns. From the transcript, it is clear that the FAA employee did not understand why the TFR would be extended over such a large area $\left(37 \mathrm{mi}^{2}\right)$. The manager replied that the commander at St. Louis County wanted 3 nautical miles and $8000 \mathrm{ft}$, but the manager "talked him down to 3 and 5" (USA Today 2014). He continued, "They finally admitted it really was to keep the media out" (USA Today 2014). Later in the same conversation, the Manager again said that 
commercial flights could go directly through the TFR. The key point was that media not be allowed.

The FAA regulation governing the issuance of TFRs has three degrees of flight restrictions available. The most severe were used in the case of Standing Rock and in Fergusson. Yet the TFR issued under FAR 01.137 for Standing Rock failed to specify any hazard or condition requiring the imposition of a TFR, as required by the regulations. To the contrary, the text of the Notice to Airmen (NOTAM) that accompanied the TFR merely mentioned a "law enforcement operation" as its raison d'etre (for full language of the TFR, Sachs 2016). Peter Sachs, reporting on the Standing Rock TFR, noted that "law enforcement operations" are not themselves hazards - unless they are, of course. In this case law enforcement had already shot eight drones out of the sky, a felony under federal law (Sachs 2016). A drone caught some of the efforts by law enforcement to shoot down drones on camera (DrOne2bwild Photography \& Video 2016).

The costs of not allowing journalists extend beyond monitoring police tactics to include violations of the law by private actors. As noted by Rhianna Lakin, a drone photojournalist, the images captured by UAS above Standing Rock demonstrated that the oil company was breaking the law, with a significant impact on the surrounding environment (Goglia 2016). These matters are important constituents of state welfare.

The FAA should not be in the game of being able to restrict media access to events of vitally important and local public concern. These issues should be dealt with at a state level, where democratic accountability and transparency allow for a full airing of citizens' concerns.

\section{Incubators of Innovation}

One of the great strengths of the state sovereignty is that it allows states to be incubators for innovation. Protected from federal overreach, and more directly answerable to the people, states can take steps to encourage new ideas and technologies, giving citizens greater freedom and states a competitive advantage over other regions. States thus act as what has been referred to as "laboratories of democracy" (Petrella v. Brownback 2016, p. 1268, citing New State Ice Co. v. Liebmann 1932, p. 311). For Brandeis, due process concerns did not provide the federal government with the right to interfere in state matters in ways that could adversely affect their markets:

To stay experimentation in things social and economic is a grave responsibility. Denial of the right to experiment may be fraught with serious consequences to the nation. It is one of the happy incidents of the federal system that a single courageous state may, if its citizens choose, serve as a laboratory; and try novel social and economic experiments without risk to the rest of the country. (New State Ice Co. v. Liebmann 1932, p. 311)

States have consistently played a critical role in fostering innovation, encouraging new ideas, and catapulting the country forward. 
At times this role is political, such as when Wyoming, lacking sufficient females, extended the right to vote to women - well before the rest of the country adopted universal suffrage. In 1889 Wyoming's state constitution read:

Male and female citizens to enjoy equal rights. The rights of citizens of the State of Wyoming to vote and hold office shall not be denied or abridged on account of sex. Both male and female citizens of this state shall equally enjoy all civil, political and religious rights and privileges. (Wyo. Const., art. $6 \S 1$ )

It took more than 30 years for the rest of the country to catch up to Wyoming. In 1920 the United States formally ratified the 19th Amendment: "The right of citizens of the United States to vote shall not be denied or abridged by the United States or by any State on account of sex" (US Const., amend. XIX). Even then, states were slow to adopt the amendment. Maryland did not ratify it until 1941. It took another 17 years before Maryland delivered the document to the US State Department (National Archives n.d.). Florida and Virginia each ratified it in the 1950s, while Florida, South Carolina, Georgia, Louisiana, and North Carolina did not pass the measure until 1969-1970. The last state to ratify the document did not do so until 1984 - nearly 100 years after Wyoming led the way (Learn NC 2009).

The US Constitution places states in a strong position to incubate new ideas by creating limits on federal control. The Founding generation granted the national government limited, enumerated powers while reserving authority, as reflected in the Tenth Amendment, for the states. Perhaps no better example could be brought to bear in the modern world of such constitutionalism-in-action as that which currently exists in regard to state UAS laws. While the federal government may have the authority to regulate drones embedded in interstate or international commerce, they have little control over citizens' or state and local governments' local use of drones or the way in which drones are used outside preestablished federal zones, such as military bases or the NAS.

UAS offers enormous opportunities. They can enable fire fighters to search buildings. They can be used in law enforcement, to find missing people and to protect officers in hot pursuit. They can be used to detonate bombs, to build bridges, and to fix structures that would present a risk to human life. They can be used to identify storm damage or to get medical supplies to individuals in remote locations. They also raise serious safety, privacy, nuisance, trespassing concerns all matters firmly in the police powers of the state. Quite apart from the significant constitutional concerns, even as purely a matter of policy, such matters, outside the safety of interstate piloted aviation, are best left in the hands of states.

\section{References}

14 C.F.R. § 1.1 (2016)

14 C.F.R. § 91.119 (2016)

14 C.F.R. $\S \S 21.191,21.193,21.195$ (2016)

14 C.F.R. pt. 45 (2016)

14 C.F.R. pt. 47 (2016) 
20 Ill. Comp. Stat. Ann. 5065/1 to 5065/99 (West 2016)

2015 Cal. Legis. Serv. 4388 (West)

2017 MT H.B. 644 (NS)

2017 UT H.B. 217 (NS)

43 U.S.C. $§ 1301-1315$ (1953)

49 U.S.C. $\S 180$ (1946)

49 U.S.C. $\$ 40102(2016)$

49 U.S.C. $\S 44101$ (2016)

$72 \mathrm{~Pa}$. Stat. and Cons. Stat. Ann. § 7201 (West 2016)

720 Ill. Comp. Stat. Ann. 5/48-3 (West 2016)

725 Ill. Comp. Stat. Ann. 167/15(2), (3) (West 2016)

725 Ill. Comp. Stat. Ann. 167/20(1)-(2) (West 2016)

A.L.A. Schechter Poultry Corp. v. United States, 295 U.S. 495 (1935)

Act for the Admission of Alabama, §6, 3 Stat. 489 (1819)

Act of Apr. 30, 1790, ch. 9, § 8, 1 Stat. 112

Air Commerce Act of 1926, Pub. L. 69-254, §§ 2-3, 44 Stat. 568

Alaska Stat. Ann. § 14.40.082 (West 2016)

Alaska Stat. Ann. § 18.65.901 (West 2016)

Alaska Stat. Ann. § 18.65.903 (West 2016)

Appeal of York Haven Water \& Power Co., 62 A. 97 (Pa. 1905)

Ariz. Rev. Stat. Ann. § 13-3729 (2016)

Ariz. Rev. Stat. Ann. § 28-8280 (2016)

Ark. Code Ann. § 16-118-111 (West 2016)

Ark. Code Ann. § 5-16-101(a) (West 2016)

Ark. Code Ann. § 5-60-103 (West 2016)

Articles of Confederation, Art. II

Balt. \& Ohio R.R. Co. v. Interstate Commerce Comm'n, 221 U.S. 612 (1911)

BBC News (2015, April 25). Japan radioactive drone: Tokyo police arrest man. Retrieved from http://www.bbc.com/news/world-asia-32465624

L. Becraft Jr., Federal jurisdiction (2017). Retrieved from http://www.constitution.org/juris/ fedjur1.htm

Bibb v. Navajo Freight Lines, Inc., 359 U.S. 520 (1959)

Black v. Am. Int'l Corp., 107 A. 737 (Pa. 1919)

Braniff Airways, Inc. v. Neb. State Bd. of Equalization \& Assessment, 347 U.S. 590 (1954)

Busting Myths about the FAA and Unmanned Aircraft (2014, March 7). Retrieved from https:// www.faa.gov/news/updates/?newsId $=76240$

Cal. Civ. Code $\S 1708.8$ (West 2015)

Cal. Civ. Code $\$ 1708.8$ (West 2017)

Cal. Civ. Code $\$ 853$ (West 2017)

Cal. Penal Code $\S 402$ (West 2016)

Y. Cho, Lost in debate: The safety of domestic unmanned aircraft systems. J. Strat. Secur. 7(4), 38-56 (2014)

Cipollone v. Liggett Grp., Inc., 505 U.S. 504 (1992)

City of Cleburne v. Cleburne Living Center, 473 U.S. 432 (1985)

Civil Aeronautics Act of 1938, Pub. L. 75-706, § 1107(i)(3), 52 Stat. 977

Commonwealth ex rel. Hensel v. Young Men's Christian Ass'n of Warren, 32 A. 121 (Pa. 1895)

Commonwealth v. Young, Brightly, N.P. 302 (Pa. 1818)

Del. Code Ann. tit. 11, $\$ 1334$ (West 2016)

M. Dewey, Water Ceremony Met with Violence by DAPL Security Morton County Police Department, [Video File] (2016a, November 3). Retrieved from https://www.youtube.com/ watch? $\mathrm{v}=0 \mathrm{~g} 4 \mathrm{vctiJ} 9 \mathrm{Jw}$

M. Dewey (2016b, November 19), DAPL continued working at night. [Video File]. Retrieved from https://www.youtube.com/watch?v=ZbtsJ5FO3Hg 
M. Dewey, Nov. 20 Police Use Percussion Grenades, [Video File] (2016c, November 27). Retrieved from, https://www.youtube.com/watch?v=1-Kbxfvno4w

D. Dishneau, Maryland Inmate Convicted in Prison Drone Conspiracy (2016, March 17), Retrieved from http://www.baltimoresun.com/news/maryland/bs-md-prison-contraband-drone20160317-story.html

Dr0ne2bwild Photography \& Video, First Drone Being Shot at in North Dakota, In Facebook [Group Page] (2016, October 24), Retrieved from, https://www.facebook.com/drone2bwild/ videos/1218059544927038/

D. Esler, Aviation Wk. FAA vs. Raphael Pirker (2015). Retrieved from http://aviationweek.com/ bca/faa-vs-raphael-pirker

FAA Modernization and Reform Act of 2012, Pub. L. No. 112-95, 126 Stat. 11 (2012)

Fair Labor Standards Act, 29 U.S.C. § 201 (2015)

Federal Aviation Act of 1958, Pub. L. No. 85-726, 72 Stat. 731 (n.d.)

Federal Aviation Administration, Model Aircraft Operating Standards (Advisory Circular 91-57) (1981)

Federal Aviation Administration, Unmanned Aircraft Systems Operations in the U.S. National Airspace System-Interim Operational Approval Guidance (AFS-400 UAS Policy 05-01) (2005)

Federal Aviation Administration, Destination 2025 (2011a). Retrieved from https://www.faa.gov/ about/plans_reports/media/Destination2025.pdf

Federal Aviation Administration, Unmanned Aircraft Systems Aviation Rulemaking Committee (2011b). Retrieved from https://www.faa.gov/regulations_policies/rulemaking/committees/ documents/media/uasarc-6172011.pdf

Federal Aviation Administration. Fact Sheet-FAA UAS Test Site Program (2013a, December 30). Retrieved from https://www.faa.gov/news/fact_sheets/news_story.cfm?newsId=15575

Federal Aviation Administration, Integration of Civil Unmanned Aircraft Systems (UAS) in the National Airspace System (NAS) Roadmap (2013b). Retrieved from https://nppa.org/sites/ default/files/UAS_Roadmap_2013.pdf

Federal Aviation Administration, Nextgen Update: 2014 (2014a). Retrieved from https://www.faa. gov/nextgen/media/NextGenUpdate2014.pdf

Federal Aviation Administration, Press Release-FAA Offers Guidance to Model Aircraft Operators (2014b). Retrieved from https://www.faa.gov/news/press_releases/news_story. cfm?newsId=16474\&cid=TW223

Federal Aviation Administration, FAA Modernization and Reform Act (P.L. 112-095) Reports and Plans (2017). Retrieved from https://www.faa.gov/about/plans_reports/modernization/

Federal Insecticide, Fungicide, and Rodenticide Act, 7 U.S.C. § 136 (2015)

Federal Register, Interpretation of the Special Rule for Model Aircraft (2014). Retrieved from https://www.federalregister.gov/documents/2014/06/25/2014-14948/interpretation-of-thespecial-rule-for-model-aircraft

L. Ferrignno, Ohio Prison Yard Free-for-All After Drone Drops Drugs (2015, August 5). Retrieved from http://www.cnn.com/2015/08/04/us/prison-yard-drone-drugs-ohio/?iid=EL

Fla. Stat. Ann. § 934.50(3)(b) (West 2016)

FPSRussia, Prototype Quadrotor with Machine Gun!. [Video File] (2012, April 23), Retrieved from https://www.youtube.com/watch?v=SNPJMk2fgJU

J.J. George, Federal motor carrier act of 1935. Cornell Law Rev. 21, 249-275 (1936)

Gibbons v. Ogden, 22 U.S. (9 Wheat.) 1 (1824)

J. Goglia, Flight Restrictions over Standing Rock: Is the FAA Effectively Taking Sides in Pipeline Dispute? (2016, November 27). Retrieved from http://www.forbes.com/sites/johngoglia/2016/ 11/27/flight-restrictions-over-standing-rock-is-the-faa-effectively-taking-sides-in-pipelinedispute/\#62cfa2a28e01

Gonzales v. Raich, 545 U.S. 1 (2005)

Greene v. Town of Blooming Grove, 879 F.2d 1061 (2d Cir. 1989) 
Gregory v. Ashcroft, 501 U.S. 452 (1991)

Griggs v. Allegheny, 369 U.S. 84 (1962)

Gun-Free School Zones Act, Pub. L. No. 101-647, §1702, 104 Stat. 4789 (1990)

H. Rep. No. 69-572 (1926)

H.R. 658 Vote Summary (2017, February 23). Retrieved from http://www.senate.gov/legislative/ LIS/roll_call_lists/roll_call_vote_cfm.cfm?congress $=112 \&$ session $=2 \&$ vote $=00015$

A. Hamilton, in Federalist no. 16, ed. by C. Rossiter (1961). The federalist papers (113-118). New York: New American Library. (Reprinted from Federalist no. 16, by A. Hamilton, 1787)

Haw. Code R. § 15-210-13 (2017)

Houston, E. \& W. Tex. Ry. Co. v. United States, 234 U.S. 342 (1914)

Idaho Code Ann. § 21-213(2)(a) (West 2016)

Idaho Code Ann. § 36-1101(b) (West 2016)

Ind. Code Ann. § 14-22-6-16 (West 2016)

Ind. Code Ann. § 35-31.5-2-186(c) (West 2016)

Ind. Code Ann. § 35-33-5-9 (West 2016)

Iowa Code Ann. § 321.492B (West 2016)

Jacobson v. Massachusetts, 197 U.S. 11 (1905)

D. Jenkins, B. Vasigh, The economic impact of unmanned aircraft systems integration in the United States. Association for Unmanned Vehicle Systems International, 2 (2013). Retrieved from https://higherlogicdownload.s3.amazonaws.com/AUVSI/958c920a-7f9b-4ad29807-f9a4e95d1ef1/UploadedImages/New_Economic\%20Report\%202013\%20Full.pdf

Joint Planning and Development Office, Unmanned Aircraft Systems (UAS) Comprehensive Plan: A Report on the Nation's UAS Path Forward (2013). Retrieved from https://www.faa.gov/about/ office_org/headquarters_offices/agi/reports/media/UAS_Comprehensive_Plan.pdf

Joint Planning and Development Office, Concept of Operations for the Next Generation Air Transportation System Version 3.2 (2010). Retrieved from http://www.dtic.mil/dtic/tr/fulltext/ u2/a535795.pdf

Jones v. Rath Packing Co., 430 U.S. 519 (1977)

Kan. Stat. Ann. § 79-220 (West 2016)

H. Kelly, How to Catch Drones Smuggling Drugs into Prisons (2016, June 24). Retrieved from http://money.cnn.com/2016/06/24/technology/dedrone-drone-prisons/

J. Koebler, The FAA Is Trying to Ban First-Person View Drone Flights (2014a). Retrieved from https://motherboard.vice.com/en_us/article/the-faa-is-trying-to-ban-first-person-view-droneflights

J. Koebler, The U.S. Government Is Trying to Fine a Drone Hobbyist for the First Time Ever (2014b). https://motherboard.vice.com/en_us/article/the-us-government-is-trying-to-finea-drone-hobbyist-for-the-first-time-ever

J. Koebler, The Commercial Drone Pilot Who Ruined the FAA's 2014 Has Settled His Case (2015). Retrieved from https://motherboard.vice.com/en_us/article/the-commercial-drone-pilot-whoruined-the-faas-2014-has-settled-his-case

J. Koebler, The Government Is Using a No Fly Zone to Suppress Journalism at Standing Rock (2016). Retrieved from https://motherboard.vice.com/en_us/article/the-government-is-using-ano-fly-zone-to-suppress-journalism-at-standing-rock

La. Stat. Ann. § 14:108 (2016)

La. Stat. Ann. § 14:283.1(A) (2016)

La. Stat. Ann. § 14:284(C) (2016)

La. Stat. Ann. § 14:337 (2016)

La. Stat. Ann. § 14:63 (2016)

La. Stat. Ann. §§ 3:41-48 (2016)

LBCk2012, Man Built a Drone that Can Aim \& Shoot a gun!. [Video File] (2016, February 5). Retrieved from https://www.youtube.com/watch?v=NB-MIUEfHN8

Learn NC, Ratification of the 19th amendment (2009). Retrieved from, http://www.learnnc.org/lp/ multimedia/12992 
J. Lichfield, French Government on High Alert After Unexplained Drone Flights over Nuclear Power Stations (2014, November 9). Retrieved from http://www.independent.co.uk/news/ world/europe/french-government-on-high-alert-after-unexplained-drone-flights-over-nuclearpower-stations-9850138.html

J. Madison, in Federalist no. 43, ed. by C. Rossiter (1961a). The federalist papers (pp. 271-280). New York: New American Library. (Reprinted from Federalist no. 43, by J. Madison, 1788)

J. Madison, in Federalist no. 45, ed. by C. Rossiter (1961b). The federalist papers (288-294). New York: New American Library. (Reprinted from Federalist no. 45, by J. Madison, 1788)

Maine, Dep't of Inland Fisheries \& Wildlife, General Hunting Provisions (2017). Retrieved from http://www.maine.gov/ifw/hunting_trapping/hunting/laws/general_provisions.htm

Maurer v. Hamilton, 309 U.S. 598 (1940)

McCulloch v. Maryland, 17 U.S. (4 Wheat.) 316 (1819)

M. McNabb, The TFR over Standing Rock: What Law Enforcement Doesn't Want You to See (2016a, November 29). Retrieved from http://dronelife.com/2016/11/29/tfr-standing-rock-lawenforcement-hiding/

M. McNabb, The Latest from Standing Rock: FAA Refuses Media Drone Permission to Fly (2016b, December 2). Retrieved from http://dronelife.com/2016/12/02/latest-standing-rock-faa-refusesmedia-drone-permission-fly/

Md. Code Ann., Econ. Dev. § 14-301 note (West 2016)

Me. Rev. Stat. Ann. tit. 25, § 4501(1) (West 2016)

Me. Rev. Stat. Ann. tit. 25, § 4501(4) (2016)

Me. Rev. Stat. Ann. tit. 25, § 4501(5) (2016)

Mich. Comp. Laws Ann. § 259.321 (West 2016)

Mich. Comp. Laws Ann. § 259.322 (West 2016)

Mich. Comp. Laws Ann. § 259.331 (West 2016)

Mich. Comp. Laws Ann. § 324.40111c(2) (West 2016)

Mich. Comp. Laws Ann. § 750.539j (West 2016)

Miss. Code Ann. § 97-29-61(1)(a) (West 2017)

Mont. Code Ann. § 46-5-109 (West 2016)

Morris v. Duby, 274 U.S. 135 (1927)

Motor Carrier Act, Pub. L. No. 255, 94 Stat. 793 (1935)

A. Mullins, Hunters Watch Out: PETA's Drones Are Flying (2013). Retrieved from http://www. peta.org/blog/hunters-watch-out-petas-drones-are-flying/

N.C. Gen Stat. Ann. § 63-95 (West 2016)

N.C. Gen. Stat. § 63-11 (1943)

N.C. Gen. Stat. Ann. § 113-295 (West 2016)

N.C. Gen. Stat. Ann. § 14-280.3 (West 2016)

N.C. Gen. Stat. Ann. § 14-401.24 (West 2016)

N.C. Gen. Stat. Ann. § 15A-300.1 (West 2016)

N.C. Gen. Stat. Ann. § 15A-300.2(a) (West 2016)

N.D. Cent. Code Ann. § 29-29.4-04 (West 2016)

N.D. Cent. Code Ann. § 29-29.4-06(1) (West 2016)

N.H. Rev. Stat. Ann. § 207:57(1) (2016)

N.L.R.B. v. Jones \& Laughlin Steel Corp., 301 U.S. 1 (1937)

N.Y. Cent R.R. Co. v. Winfield, 244 U.S. 147 (1917)

National Archives, Ratification of 19th Amendment: Tennessee - August 24, 1920. Retrieved from, https://www.archives.gov/education/lessons/woman-suffrage/ratification-tn.html [https://web.archive.org/web/20160929122352/http://www.archives.gov/education/lessons/womansuffrage/ratification-tn.html]

National League of Cities, Cities and Drones: What Cities Need to Know About Unmanned Aerial Vehicles (UAVs) (2016)

Nev. Governor's Off. Econ. Dev, Nevada Unmanned Aerial Vehicles (2012). Retrieved from http:/ /diversifynevada.com/key-industries/aerospace-defense/uav

Nev. Rev. Stat. Ann. § 360.753 (West 2015) 
Nev. Rev. Stat. Ann. § 493.020 (West 2015)

Nev. Rev. Stat. Ann. § 493.100 (West 2015)

Nev. Rev. Stat. Ann. § 493.103 (West 2015)

Nev. Rev. Stat. Ann. § 493.106 (West 2015)

Nev. Rev. Stat. Ann. § 493.109 (West 2015)

Nev. Rev. Stat. Ann. § 493.112 (West 2015)

Nev. Rev. Stat. Ann. § 493.115 (West 2015)

Nev. Rev. Stat. Ann. § 493.130 (West 2015)

New State Ice Co. v. Liebmann, 285 U.S. 262 (1932) (Brandeis, J., dissenting)

New York v. Miln, 36 U.S. (11 Pet.) 102 (1837)

NODAPL Protest, Digital Smoke Signals Drone Footage 20 November 2016, [Video File] (2016,

November 1). https://www.youtube.com/watch?v=MXQsJpL-KMw

Occupational Safety and Health Act, 29 U.S.C. § 651 (2015)

Okla. Stat. Ann. tit. 3, § 3422 (West 2016)

Op. Att'y Gen., Opinion No. 14-051 (Oct. 9, 2014)

Operation and Certification of Small Unmanned Aircraft Systems, 81 Fed. Reg. 42,064 (August 29, 2016)

Or. Rev. Stat. Ann. § 215.213 (West 2016)

Or. Rev. Stat. Ann. § 215.283 (West 2016),

Or. Rev. Stat. Ann. § 498.128(1) (West 2016)

Or. Rev. Stat. Ann. § 837.340 (West 2016)

Or. Rev. Stat. Ann. $\$ 837.345$ (West 2016)

Or. Rev. Stat. Ann. § 837.360(1) (West 2016)

Or. Rev. Stat. Ann. § 837.365 (West 2016)

Or. Rev. Stat. Ann. $\$ 837.375$ (West 2016)

Or. Rev. Stat. Ann. § 837.380 (West 2016)

Or. Rev. Stat. Ann. $\$ 837.995$ (West 2016)

Or. Rev. Stat. Ann. $\S \S 837.310,837.320$ (West 2016)

Or. Undesignated Enactments ch. 72, § 13 (West 2016)

Or. Undesignated Enactments Ch. 72, § 5 (West 2016)

Pennsylvania v. Nelson, 350 U.S. 497 (1956)

PETA, Hunters Watch Out: PETA's Drones Are Flying, [Video File] (2013, October 23). Retrieved from https://www.youtube.com/watch?v=mJz-X7Y_fLc

Petrella v. Brownback, 787 F.3d 1242 (10th Cir. 2015)

Pollard v. Hagan, 44 U.S. (3 How.) 212 (1845)

Portland Press Herald, New Hampshire Bans Drones for Hunting (2015, May 21). Retrieved from http://www.pressherald.com/2015/05/21/new-hampshire-bans-drones-for-hunting/

Prigg v. Pennsylvania, 41 U.S. (16 Pet.) 539 (1842)

Registration and Marking Requirements for Small Unmanned Aircraft, 80 Fed. Reg. 78,594 (2015, December 16) (interim final rule)

Registration of Small Unmanned Aircraft Systems Operated Under Exemptions Issued by the FAA, 81 Fed. Reg. 23544 (2016, April 21)

Regulation of Vehicles on Rural Highways, 1931 Tex. Gen. Laws 507

Rice v. Santa Fe Elevator Corp., 331 U.S. 218 (1947)

T.V. Ruptly, USA: Drone Dodges Water Cannon to Capture Dakota Pipeline Protest, [Video File] (2016, November 20). Retrieved from https://www.youtube.com/watch?v=SYdVcJyhSPg

S. Pac. Co. v. Arizona ex rel. Sullivan, 325 U.S. 761 (1945)

S. Rep. 75-1661 (1938)

S. Res. 146, 74th Cong (1935)

P. Sachs, Why Is There a TFR over Standing Rock? (2016, November 27). Retrieved from http:// dronelawjournal.com/why-is-there-a-tfr-over-standing-rock/

M. Schmidt, Airmail via Drones Is Vexing for Prisons (2015, April 23). Retrieved from https:// www.nytimes.com/2015/04/23/us/drones-smuggle-contraband-over-prison-walls.html?_r=0 
K. F. Seachrist, Federal Government May Force Farmers to Get CDL to Operate on the Road (2011, August 11). Retrieved from, http://www.farmanddairy.com/news/federal-governmentmay-force-farmers-to-get-cdl-to-operate-on-roads/28050.html

Skysign Int'l, Inc., v. Honolulu, 276 F.3d 1109 (9th Cir. 2002)

A. Smith, Drones Armed with Guns and Flamethrowers Face Ban (2016, March 2). Retrieved from http://money.cnn.com/2016/03/02/technology/drones-guns-flamethrowers/?iid=EL)

South Carolina State Highway Dept. v. Barnwell Bros., 303 U.S. 177 (1938)

Southern Ry. Co. v. United States, 222 U.S. 20 (1911)

Sproles v. Binford, 286 U.S. 374 (1932)

State of N.J., Dep't of Agric, Motor Vehicle Laws and Regulations Impacting Farmers (2017, March 27). Retrieved from http://www.nj.gov/agriculture/divisions/md/prog/ farmermotorvehicles.html

K. Steinmetz, Colorado Town Won't Issue Drone-Hunting Licenses (2014, April 2). Retrieved from http://time.com/46327/drone-hunting-deer-trail/

T. Stelloh, et al., Dakota pipeline: protesters soaked with water in freezing temperatures (2016, November 21). Retrieved from http://www.nbcnews.com/storyline/dakota-pipeline-protests/ dakota-pipeline-protesters-authorities-clash-temperatures-drop-n686581

Tenn. Code Ann. § 39-13-609(g) (West 2016)

Tenn. Code Ann. § 39-13-902 (West 2016)

Tenn. Code Ann. § 39-13-903(a) (West 2016)

Tenn. Code Ann. § 39-14-405 (West 2016)

Tenn. Code Ann. § 70-4-302(a) (West 2016)

Tex. Gov't Code Ann. $\$ 411.062$ (West 2015)

Tex. Gov't Code Ann. § 423.002(a) (West 2015)

Tex. Gov't Code Ann. § 423.003(a)-(c) (West 2015)

Tex. Gov't Code Ann. § 423.0045 (West 2015)

Tex. Gov't Code Ann. $\$ 423.007$ (West 2015)

Tex. Gov't Code Ann. § 423.008(a)-(b)(1) (West 2015)

Tex. Gov't Code Ann. §§ 423.001 (West 2015)

The Lip TV, Gun Drone Designer Creates Flame Thrower Drone, [Video File] (2016, June 9).

Retrieved from https://www.youtube.com/watch?v=Dwmh7ddPsk4

Thomas Cusack Co. v. City of Chicago, 242 U.S. 526 (1917)

U.S. Const. amend. V

U.S. Const. amend. X

U.S. Const., amend. XIX

U.S. Const. art. I

U.S. Const. art. IV

U.S. Const. art. VI

Unif. Aeronautics Act \$2-4 (1922)

United States v. Bevans, 16 U.S. (3 Wheat.) 336 (1818)

United States v. Causby, 328 U.S. 256 (1946)

United States v. Darby, 312 U.S. 100 (1941)

United States v. Lopez, 514 U.S. 549 (1995)

United States v. Pa. Salt Mfg. Co., 16 F.2d 476 (E.D. Pa. 1926)

Unmanned Aircraft Operations in the National Airspace System, 72 Fed. Reg. 6689 (2007)

USA Today, U.S. Approved Ferguson No-Fly Area to Block Media (2014, November

2). Retrieved from http://www.usatoday.com/story/news/nation/2014/11/02/ferguson-flightrestrictions-helicopters-protests/18380867/

Utah Code Ann. § 63G-18-105(1) (West 2016)

Utah Code Ann. § 65A-3-2.5(3)(b) (West 2016)

Va. Code Ann. § 19.2-60.1(E) (West 2016)

Village of Euclid v. Ambler Realty Co., 272 U.S. 365 (1926)

Vt. Stat. Ann. tit. 13, § 4018 (West 2016)

Vt. Stat. Ann. tit. 20, § 4622(d) (West 2016) 
W. Va. Code Ann. § 20-2-5(4)-(5) (West 2016)

Wainwright v. McCullough, 63 Pa. 66 (1869)

Wickard v. Filburn, 317 U.S. 111 (1942)

Wis. Stat. Ann. § 114.045 (West 2016)

Wis. Stat. Ann. § 29.083 (West 2016)

Wis. Stat. Ann. § 941.292 (West 2016)

Wyo. Const., art. $6 \S 1$ 